\title{
Müzik Performansı Analizinde Kıyaslamalı Değerlendirme ve Yorumda Estetik Arayışı*
}

\section{Comparative Evaluation in Music Performance Analysis and the Quest for Esthetics in Interpretation}

\author{
İsmet KARADENİ ${ }^{1}$
}

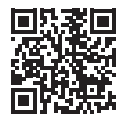

DOI: $10.26650 / C O N S 2021-981170$

\begin{abstract}
* Bu çalışmanın bir bölümü, SANART Estetik ve Görsel Kültür Derneği tarafından 2019 yılında gerçekleştirilen 3. Türkiye Estetik Kongresi'nde sözlü olarak sunulmuştur.

'Dr., Hacettepe Üniversitesi, Ankara Devlet Konservatuvarı, Müzik Bilimleri Bölümü, Ankara, Türkiye
\end{abstract}

ORCID: I.K. 0000-0003-1530-2506

\section{Sorumlu yazar/Corresponding author:} Ismet KARADENIZ,

Hacettepe Üniversitesi, Ankara Devlet Konservatuvarı, Müzik Bilimleri Bölümü, Ankara, Türkiye

E-posta/E-mail: ismetkaradeniz@outlook.com

Başvuru/Submitted: 10.08 .2021

İlk Revizyon/Revision Requested: 20.11.2021

Son Revizyon/Last Revision Requested:

06.12.2021

Kabul/Accepted: 13.12.2021

Online Yayın/Published Online: 29.12.202

Atıf/Citation: Karadeniz, I. (2021). Müzik performansı analizinde kıyaslamalı değerlendirme ve yorumda estetik arayışı. Konservatoryum - Conservatorium, 8(2), 149-177. https://doi.org/10.26650/CONS2021-981170

\section{öz}

Klasik Batı Müziği eserlerinin yazılı bir materyalden yola çıkılarak seslendiriliyor oluşu, yorumlarını birer yeniden yaratım nesnesi noktasına taşımaktadır. Dolayısıyla, bestecinin üretiminin ardından 'yorum' aracılığıyla aktarılan eserde, yorumcunun etki ve katkısı kaçınılmazdır. Her performansın bir yorum olduğu ve her bir yorumda eserin farklı noktalarının aydınlatıldığı -veya aksine, göz ardı edildiği- düşüncesinden hareketle, yorumlar arasındaki doğal farklılıkların eserle olan ilişkisinin, 'esere uygunluk' bağlamında incelenmesi mümkündür. Felsefî hermeneutiğe göre ancak'kabul edilebilirlik' çerçevesinde değerlendirilebilen yorumların, eserin karakterine dair nitelikleri ne seviyede koruduğu çıkarımı için ise estetik birtakım kriterlere gereksinim duyulmaktadır. Farklı görüşlerin genel bir yorum eleştirisi standardizasyonunun parçası olabilmesi için; yorumcunun, eserin yeniden yaratımındaki yetkinliğinin yanı sıra entelektüel birikiminin rolü ve esere bu kanalla sunacağı katkının sınırları, ancak bu kriterler sayesinde nesnel olarak ölçülebilmektedir. Bir müzik eserinin herhangi bir yorumunu bir diğerine göre daha 'makul' kılan detayların niteliğine odaklanan bu çalışmada, eleştirel standartların çeşitliliğine dikkat çekmek üzere; Barok, Klasik, Romantik ve Çağdaş Dönem eserlerinden seçilen yorum örnekleri, 'kıyaslamalı değerlendirme' yaklaşımıyla incelenmiş ve bu değerlendirme doğrultusunda, yorumcuların eserle ilişkilendirdikleri müzikdışı göndermelerin, yorumun kimliğindeki önemi ortaya konmuştur.

Anahtar Kelimeler: Müzik performansı analizi, yorum, estetik

\begin{abstract}
Because western classical music works are performed based on written materials, each interpretation becomes an object of re-creation. Therefore, the influence and contribution of the interpreter are inevitable in the composition communicated through performance following a composer's creation. Based on the notion that each performance is an interpretation and that the different points of the work are highlighted or, on the contrary, ignored in each of the performances, examining the relationship between natural differences in interpretation and the work in the context of the appropriateness to the composition is possible. Several esthetic criteria are required to explain the degree to which interpretations, which can only be evaluated within the framework of admissibility according to philosophical hermeneutics, preserve
\end{abstract}


the characteristics of the work. These criteria can be used to objectively evaluate the role of the interpreter's intellectual background and the limits of the contribution of the work to the composition. In doing so, different views become part of the general standardization of performance criticism apart from the competence of the interpreter. Thus, this study focuses on the quality of details that render any interpretation of a musical work more plausible than another to draw attention to the diversity of critical standards. Moreover, it examined performance examples from works selected from the Baroque, Classical, Romantic, and Contemporary periods through comparative criticism. The results reveal the importance of extra-musical references associated with the work by interpreters to establish the character of the interpretation.

Keywords: Music performance analysis, interpretation, esthetics

\section{EXTENDED ABSTRACT}

While each performance attempts to mediate between tradition and innovation, it in turn becomes part of the remembered tradition.

José A. Bowen (2001, p. 427)

Western classical music works are performed on the basis of written materials. As such, each interpretation becomes an object of re-creation. Therefore, the influence and contribution of the interpreter are inevitable in the composition, which are communicated through performance following the composition. Based on the notion that each performance is an interpretation, whereas the different points of a work are highlighted or ignored in each of the performances, examining the relationship between natural differences in interpretation and the work is possible in the context of the appropriateness of a composition. At this point, the critic profile that is added to the composer-interpreteraudience chain gains importance. The critic may objectively evaluate the role of the interpreter's intellectual background and the limits of its contribution to the composition through this channel following specific esthetic criteria. In this manner, any critical view can become part of the general standardization of interpretation criticism apart from the competence of the interpreter. Various inferences obtained through analysis of music performance, which provides opportunities for comparing between interpretations, play a significant role in lending comprehensibility to the relatively abstract standards inherent to art.

This study employs the comparative criticism approach and aims to shed light on the effect of the hue of an interpretation detail on the entire composition. To this end, two 
performances each from four compositions selected from the Baroque, Classical, Romantic, and Contemporary periods were analyzed. The sections of the works being examined are under the titles of improvisational, expressive, plausible, and intellectual interpretation, respectively. These works were examined from the context of the interpreters' fidelity to the composition and their addition to the score. Their approaches were evaluated by analyzing their performances based on duration, dynamics, and pitch. These measurements were achieved using Audacity 2.4.2 ${ }^{\circledR}$.

The sections examined can be summarized as follows.

- First Section: The third movement of J. S. Bach's Sonata for Violin and Harpsichord, No. 3 (BWV 1016) is reshaped by pianist Glenn Gould's improvisational interpretation approach, which reflects the Baroque Period. Gould approached the ornament style of the period by stretching the score with the addition of a minimal broken chord symbol ( $)$ brought with by the Baroque understanding in the first measures. Moreover, Gould made an improvement that provided a connection with the melodic line that would come in the following measures.

- Second Section: In the arietta selected from W. A. Mozart's The Marriage of Figaro (KV 492), one can witness the expressive interpretation approach of mezzo-soprano Cecilia Bartoli. She emphasized the dramatic expression that the character (Cherubino) requires with a nuance ( $p p p)$ added at the end of the arietta through exaggeration.

- Third Section: The interpretations of Valery Gergiev and Leif Segerstam on the last movement of Rimsky-Korsakov's Scheherazade (Op. 35) were compared within the framework of plausible interpretation. Initially, although evaluating the theatrical scene is seemingly plausible as an approach to strengthen the narration, which Segerstam does not refrain from adding with external voices, doing so is far from plausible due to the interpretation's marginal quality that precedes the music according to philosophical hermeneutics.

- Fourth Section: This section includes an example of an intellectual interpretation of Saygun's Yunus Emre (Op. 26). Tenor Ömer Yılmaz added two grace notes at the end of the sentence of the Recitativo, one of which creates a microtonal interval. $\mathrm{He}$ presented an interpretation with the awareness of the essential material of contemporary Turkish Music and the attitude of Turkish folk music within the work. 
This repertoire, which includes works from different centuries, reveals the decisiveness of the historical, cultural, and contextual frameworks in terms of the freedom, permissiveness, and creativity of the inventive interpreters of the modern era. The common point of these types of interpretation is that the details highlighted in the sections are considered and refined additions, which are created through esthetic concern that cannot be identified as mistakes or instant additions. In addition, it is interesting that each most creative and most indefensible interpretation was realized by stretching the fidelity to the musical score. Therefore, this result underscores the interpreter, that is, the subject whose steps we follow between performance and score, as positioned in a gray area. 


\section{Giriş}

Her performans gelenek ile yenilik arasında aracılık etmeye çalışırken, anılan geleneğin bir parçası haline gelir. ${ }^{1}$

José A. Bowen (2001, s. 427)

Klasik Batı Müziği eserlerinin yazılı bir materyalden yola çıkılarak seslendiriliyor oluşu, yorumlarının, birer yeniden yaratım nesnesi olarak değerlendirilmesinde önemli rol oynamaktadır. Bestecinin ürettiği 'tamamlanmış’ eserin dinleyiciye yorum aracılığıyla ulaşması dolayısıyla, eser üzerinde yorumcunun etki ve katkısının varlığı da kaçınılmazdır. Kaldı ki yorumcu sözcüğü, 'açıklayan, tercüme eden' anlamındaki (Lewis, 1891, s. 436) etimolojik kökeni (Lat. interpres) itibarıyla da söz konusu 'aracılık' işlevini ön planda tutmaktadır. Her icranın bir yorum olduğu ve her yorumda eserin farklı noktalarının vurgulandığı, aydınlatıldığı, veya aksine, göz ardı edildiği düşüncesinden hareketle, yorumlar arasında kendiliğginden oluşan farklılıkların eserle olan ilişkisi, 'esere uygunluk’ bağlamında değerlendirmeye açıktır. Felsefî hermeneutiğe göre (Gadamer, 2008, 2009), 'doğru’ veya 'yanlış’ biçiminde nitelenmesi mümkün olmayan, ancak ve ancak 'kabul edilebilirlik' çerçevesinde değerlendirilebilen yorumların, eserin temel niteliklerini ne seviyede ön planda tuttuğu konusu için ise birtakım estetik kriterlere gereksinim duyulmakta ve bu noktada, besteci-yorumcu-dinleyici zincirine dâhil olan eleştirmen profili önem kazanmaktadır. Eleştirel bir görüşün, genel bir yorum eleştirisi standardizasyonunun parçası olabilmesi için; yorumcunun, eserin yeniden yaratımındaki yetkinliğinin yanı sıra entelektüel birikiminin de rolü ve esere bu kanalla sunduğu katkının, bahsi geçen estetik kriterler doğrultusunda değerlendirilmesi gerekmektedir.

Piyano resitallerindeyiz. Virtüoz Kemff, Beethoven'ın Appassionata'sın1 yorumluyor. Beethoven bunu yazarken özdeş coşkudaydı. Kısa boyu, geniş alnı, iri çenesiyle, ellerinin damarları çıkık, dudakları titreyerek... Kemff de büyük, kuyruklu piyanosunun başında bir ikinci Beethoven'dı. Bütün dinleyiciler aynı ruh ve yapıdaydı. Bu birey-dehânın yarattı̆̆ı neydi? Ve hangi etkiyle yaygınlaşıyordu (Göktepe, 1984, s. 321)?

1 Tüm çeviriler -kaynakçada aksi belirtilmedikçe- makale yazarı tarafından yapılmıştır. 
Salâhattin Göktepe'nin, bir yorumcudan yansıyan etkinin heyecanıla sorduğu bu sorunun genişleterek, çalışmanın temel sorularından biri haline getirilmesi mümkündür: Eseri alımlayan dinleyici için, bir yorumun; onu estetik açıdan farklı kılan niteliği nedir ve eserle bağlantısı ne yolla kurulmaktadır?

Yorumlar arasında karşılaştırma yapma imkânı sağlayan müzik performansı analizi ile elde edilen çeşitli çıkarımlar, sanat alanına içkin ve görece 'soyut' standartların belirginleşmesinde önemli role sahiptir. Ancak bu noktada, bir 'entelektüel faaliyet' (Bujić, 2002, s. 324) olarak nitelenen müzik kritiği konusuna önem atfedilmesi gerekir.

Müzik eleştirisi olarak adlandırılabilecek organize bir bilgi bütününün olmadığını ifade eden müzikolog Alan Walker (1998, para. 2), elde somut kriterler olmadan yapılan her eleştirinin öznel birtakım fikirlerle aynı seviyede kalma ihtimalinin kaçınılmazlığına işaret eder ve bir eleştirmenin görüşlerini diğerlerinden 'daha doğru' yapanın ne olduğunu sorgular. Bu bağlamda yorumcunun konumu ve sınırları da eleştiri alanında her dönem tartışılagelmiş bir açmaz olarak karşımıza çıkar. Örneğin; konuya, yorumcunun özgürlüğü ve 'sorumluluğu' açısından yaklaşan bir görüş, piyanist ve besteci Vladimir Horowitz’e aittir:

Tabiri caizse müziği açmalı ve notaların arkasında ne olduğunu görmelisiniz, çünkü notalar ister Bach'ın ister bir başkasının müziği olsun, aynıdır. Ancak notaların arkasında başka bir şey anlatılır ve yorumcunun bulması gereken de budur. Yorumcu, oturup bir pasajı bir şekilde çalabilir ve belki bir sonrakini abartabilir, ama her halükârda müzikle bir şeyler yapmalıdır. En kötüsü, hiçbir şey yapmamak (aktaran Mach, 1991, s. 116).

Bu yaklaşımın aksini ise Önder Kütahyalı (1996), yorumcunun 'sınırlılığı'nı ön planda tutan Ernest Newman'dan aktarır:

Kabul etmek gerekir ki bir yorumcu, sahip olduğu zihinsel ve fiziksel yapıs1nın besteciden gelen fikirlere kişisel bir renk ve çeşitlilik katmasını önleyemez; ama o, tam bu noktada durmalı, kendi benliğini bilerek müziğe aşılamamalıdır. Yapıtta olmayanları, bestecinin söylemediği şeyleri, yine besteci adına notadan okuma eğilimini dizginlemelidir. Bestecinin koyduğu imlere kesinlikle bağlı kalmalıdır. İşte o zaman her şey iyi gidecektir.

Newman'a göre konuyu bu denli basite indirgemek, yorumcuyu bazı ayrıntılar dışında sadece nota değerlerini, ses yüksekliklerini, gürlükleri ve tınıları çalan 
bir aracı gibi görmek olur. Böylece yorum ve yorumcu sorunu daha da karmaşık nitelikler kazanacaktır (s. 13).

Her durumda bir aracılık girişimi olarak nitelenen yorumun liyakatle yapılan değerlendirmesinin, pek çok görüş ayrılıklarına sahne olan böylesi bir 'eleştirel' platformda kendini zorlukla ispatlayabileceği açıktır. Ne var ki, belli detaylara odaklanarak somut kriterler üreten; kıyaslamalı, tarihsel, estetik veya formalist değerlendirmelerle bu sorunun üstesinden gelmek kısmen mümkündür. Müzik yazarı ve eleştirmeni Michel-Dimitri Calvocoressi'ye göre (1923, s. 72), değerlendirmede ve yargılamada bulunacak olan kişi; mevcut eleştiri yöntemlerini, ileri sürdüğü nesneye uygun olarak elemeli, adapte etmeli, dönüştürmeli ve (eklemelerle) artırmalıdır. Bu çalışma da -her ne kadar, analiz içeren kimi noktalarda tarihsel (Moran, 1988, s. 66) ve formalist eleştiri (Everist, 2001, s. 378-379) alanlarına yaklaşsa da-genel itibarıyla 'kıyaslamalı’² bir değerlendirme yaklaşımını baz almakta ve yorumun detayındaki bir 'rengin', yapıtın bütününe olan etkisine bu yolla ışık tutmayı amaçlamaktadır.

\section{Yöntem}

Çalışmada, yorumcu öznenin etkisinin, Klasik Batı Müziği’nin farklı dönem ve türde eserleri üzerindeki ortak 'yaratıcılığına' dikkat çekmek amacıyla; Barok Dönem'den bir salt müzik (sonat), Klasik Dönem'den bir vokal müzik (opera), Romantik Dönem'den bir program müziği (senfonik süit) ve Çağdaş Dönem'den -bünyesinde geleneksel müzik öğeleri de barındıran- bir vokal müzik (oratoryo) eser kesiti seçilmiştir. Ardından her bir kesit için, birbirlerinden farklı yorum yaklaşımlarına sahne olmaları dolayısıyla tercih edilen ikişer performans kaydı, 'kıyaslamalı değerlendirme' çerçevesinde mercek altına alınmıştır.

Her birinde öne çıkan niteliklere istinaden, bu çalışma özelinde, sırasıyla 'doğaçlamacı, anlatımcı, kabul edilebilir ve entelektüel yorumculuk' başlıkları altında odaklanılan yorum kesitleri; yorumcuların, esere sadakat ve notaya katkıları bağlamında incelenmiş ve yaklaşımları, yorumlarının, süre, gürlük ve frekans değeri bazında ölçülmesiyle değerlendirilmiştir. Söz konusu ölçümler Audacity 2.4.2® programı aracıllığyla gerçekleştirilmiştir.

2 Calvocoressi'ye (1923) atıfta bulunan Özkan (2007, s. 62), 'kıyaslamalı eleştiri’ yaklaşımını; besteci, yorumcu veya müzik eserinin niteliklerinin, bir diğer besteci, yorumcu veya müzik eseri ile kıyaslanması yoluyla yargıya varılması olarak tanımlar. 


\section{Analiz ve Bulgular}

Çalışmada ele alınan yorum kayıtlarına şu QR kodlar aracılığıyla ulaşılması mümkündür:

Tablo 1. Çalışmada incelenen eser kesitlerine ilişkin QR Kodlar

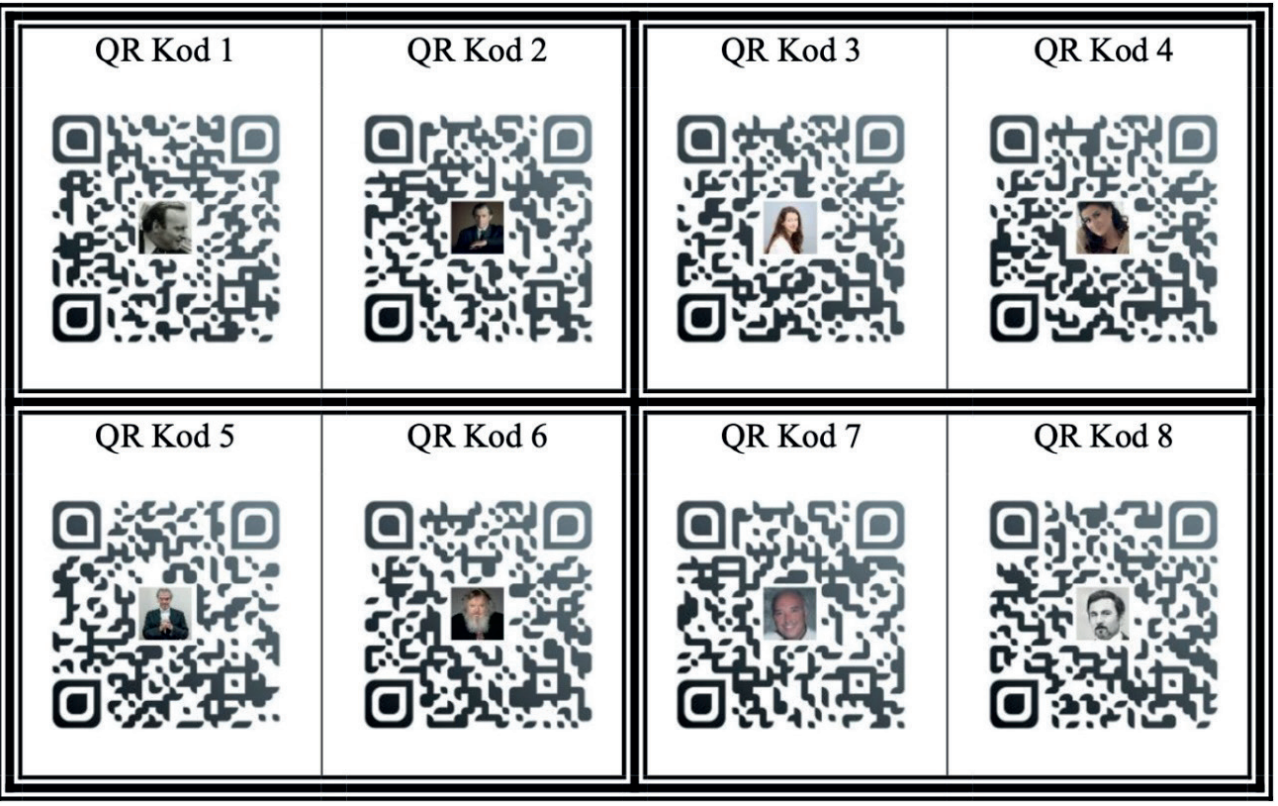

\section{Kesit 1: Doğaçlamacı Yorumculuk}

- J. S. Bach, Keman ve Klavsen için Altı Sonat, No. 3, BWV 1016, Mi Majör, III. Adagio ma non tanto

Özellikle J. S. Bach yorumculuğu ile ünlenmiş olan Kanadalı piyanist Glenn Gould'un, yorumlarıyla 18. yüzyıl müziğine katmak istediği doğaçlama unsuru ve Barok vurgusu (Monsaingeon, 1989, s. 35), kendisinin Barok Dönem yorumlarına da ışık tutmaktadır (Karadeniz, 2017, s. 276).

J. S. Bach'ın, keman ve klavsen için 3. Sonat'ının (1717-1723) üçüncü bölümünün, Karl Richter (klavsen) ve Leonid Kogan (keman) tarafindan gerçekleştirilen 1972 tarihli yorumunda (Bach, 2012, parça 11; SuperClassic Channel, 2019) klavye partisinde, notaya bağlı kalınarak ö1-123 arasında görülen dikey armoni yapılarının birebir icra edilmesi

3 Ölçü numaraları metin boyunca ö1-12 şeklinde ifade edilmiştir. 
kabul görür bir yorum niteliği taşımaktadır (bkz. Tablo 1: QR Kod 1). Ancak Gould'un, bu esere, çizgisel armoni kaygısı güderek katacağı bir 'yenilik' bulunmaktadır:

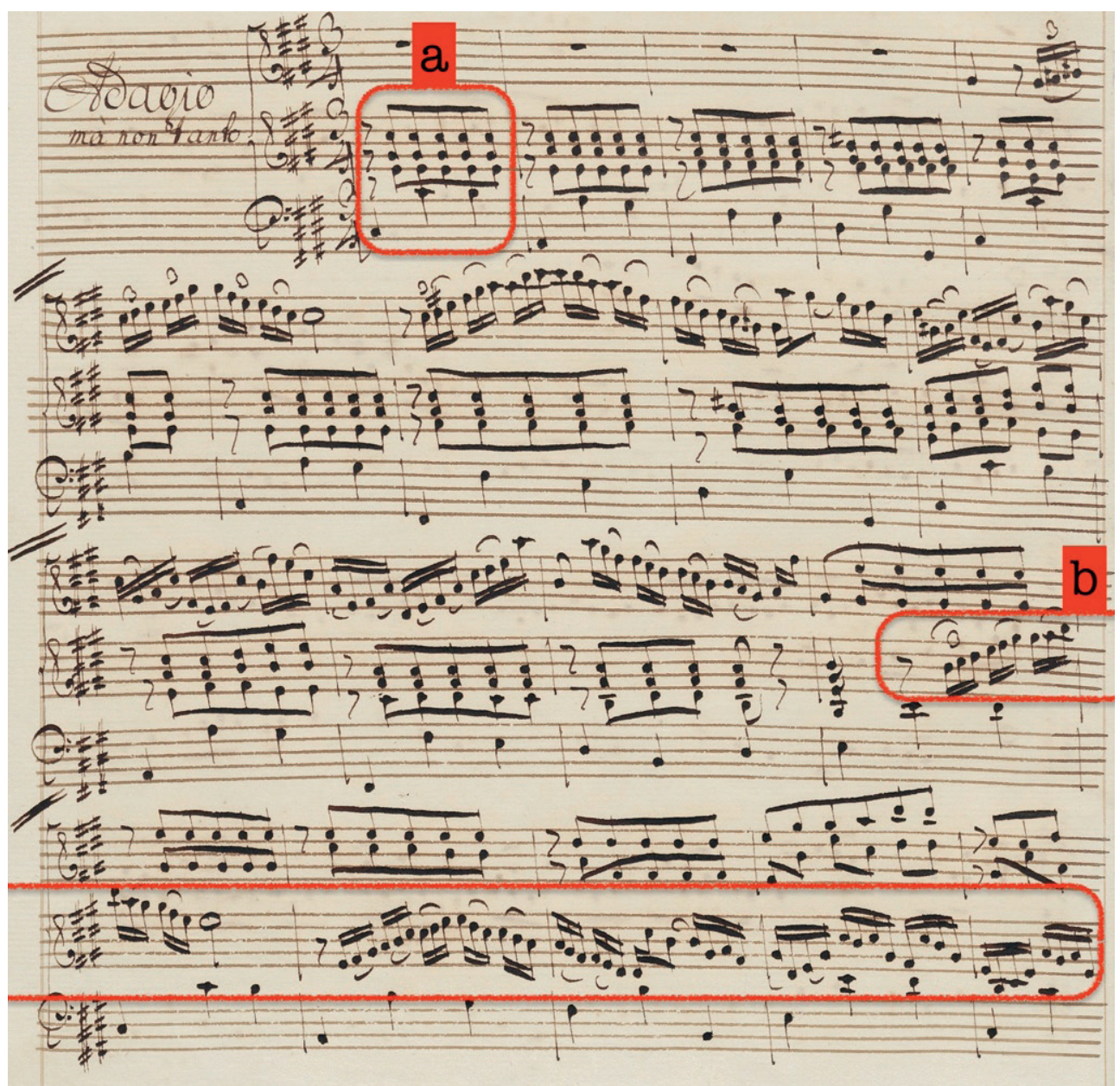

Örnek 1. J. S. Bach, BWV 1016, III, ö1-18 (Bach, t.y., s. 7).

Eserin, -bestecinin kayınpederi ve kopyacısı olan- Johann Christoph Altnickol tarafindan 1747-1759 yılları arasında bir tarihte yazılmış olduğu tahmin edilen nüshasında görüldüğü üzere, ö13'te başlayan çizgisel yapı [b], armoniyi oluşturan seslerin aynı anda gelmediği bir doku yaratmakta ve ilk 12 ölçüdeki yapıya [a] tezat oluşturmaktadır. Gould, bu yapılar arasında bütünlük sağlamak adına ve Bach'ın döneminde, dikey (vertical) ve yatay (horizontal) armoniler arasındaki bağlantının henüz bilinmediği (Monsaingeon, 1989, s. 36) gerekçesiyle, ö13'e kadar olan ve dikey armoni oluşturan akorları 'kırarak' icra etmekte, 
bu yolla eserin tümünde çizgisel armoni kullanma olanağı sağlamaktadır (Karadeniz, 2017, s. 278). Kendisi (Bach, 1994, parça 11; Gould, 2017), söz konusu akorları -dönemin geleneğinde zaten var olan- ufak bir 'doğaçlama unsuru' dokunuşu ile, hızla çalınan birer arpej biçiminde yorumlamaktadır (bkz. Tablo 1: QR Kod 2).

Eserin ilk ölçüsüne ilişkin olarak her iki yorum kaydının karşılaştırmalı spektrum görüntüsü şu şekildedir (1.1. Richter; 1.2. Gould):

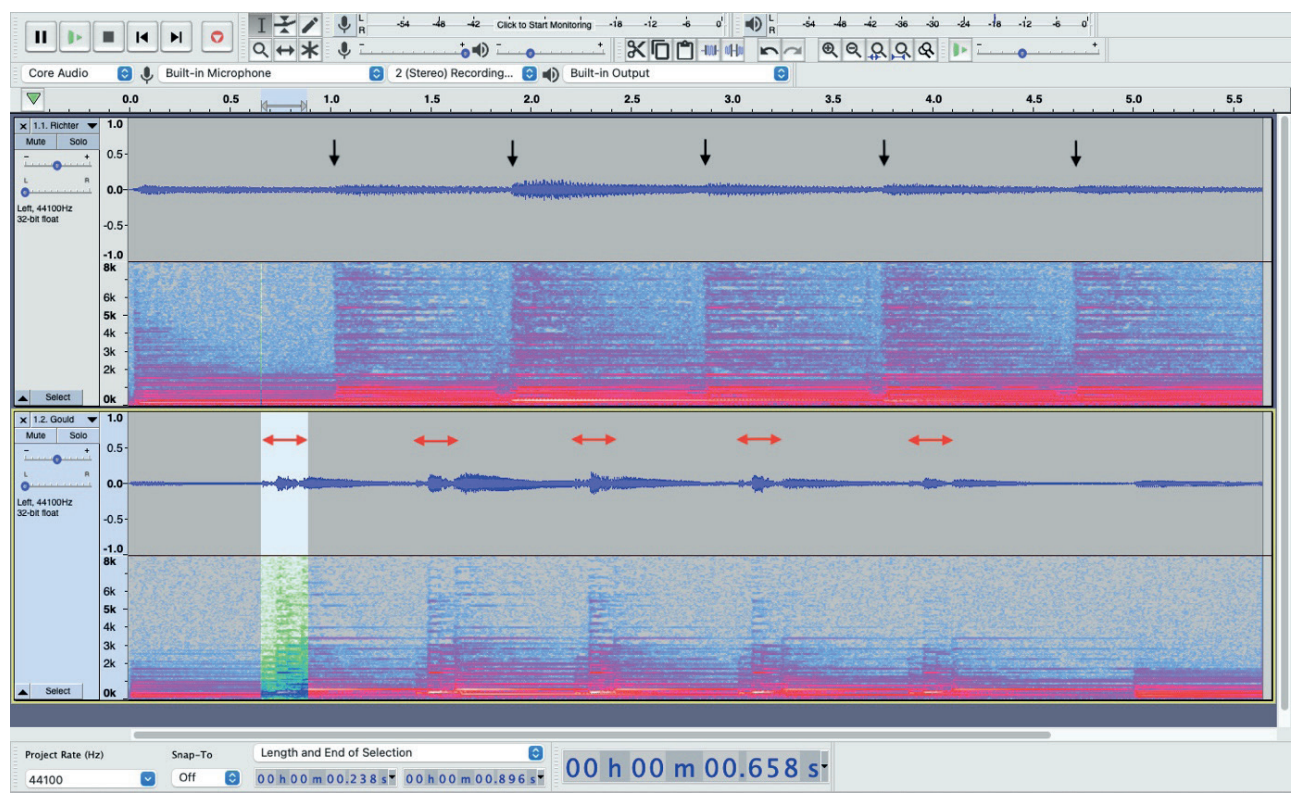

Şekil 1. J. S. Bach, BWV 1016, III, ö1: Karşılaştırmalı spektrum görüntüsü [Richter - Gould].

Şekilde açıkça görüldüğü üzere; öl'de yer alan akorları Karl Richter, yazıldığı gibi, aynı anda icra etmekte; buna karşın Glenn Gould söz konusu akorların her birini yaklaşık 0,3 sn. süresinde kırarak yorumlamaktadır. Böylelikle çizgisel yapı, tam da Barok Dönem'in 'doğaçlamacı yorumcu' karakterinin gerektirdiği şekilde, bölümün tamamına hâkim olabilmektedir.

Sahne sanatları felsefecisi Paul Thom (2006, s. 439), temsilî yorumların, eserin kimi belirgin yönlerini öne çıkarırken, diğer yönlerini ise görmezden geldiğini veya çarpıttığını ifade eder. Gould da bu yorumunda, eserin giriş akorlarının dikey armoni oluşturacak şekilde yazılmış olmasını deyim yerindeyse göz ardı etmekte ve eserin devamı ile uyum sağlayacak bir yaklaşım yoluna gitmektedir. Bu yaklaşımı; 'notaya sadakat' nok- 
tasında eleştirilebilir olmasının yanı sıra, bünyesinde, esere yönelik bütüncül bakış açısı ile açıklanabilir bir estetik kaygı taşımaktadır.

Önder Kütahyalı (1996), yorumcu tarafından eserin nesnesine (notaya) yapılan eklemeleri şöyle ifade eder: "Yorumcunun, yeniden yaratma olgusu sırasında yaptığ katkı, birtakım süslemelerin ya da geçitlerin doğaçtan çalınması değildir. Onun kişiliği ve teknik donanımı, notada gösterilen ya da gösterilmeyen birçok ayrıntıyı etkiler" (s. 12). Kütahyalı'nın değindiği ayrıntıların; somut notaları soyut müziğe, ya da aksine, soyut anlamı somut sese dönüştüren unsurlar olarak değerlendirilmesi mümkündür.

Örneğin, Hamilton (2008), "Müziğin biçimsel olarak soyut olduğu söylenebilir, ancak ifade açısından insanîdir ve ifade esastır. Bach'ın müziği genellikle en soyut ses yapısı olarak kabul edilir, fakat kendi zamanında anlamlar taşıordu ve bu [bugün] yorumlama ile gerçekleştiriliyor" (s. 114) tespitinde bulunur. Busoni’nin (1911) de konuya ilişkin yaklaşımı dikkate değerdir:

Sanatın dünyevilik tarafından tehdit edildiği yerde, onu yükseltmek ve ilkel özünü (ilk ruhunu) ona yeniden bağışlamak, yorumun bir parçasıdır. Notasyon, müzik eserinin yazımı, onu daha sonra kullanmak amacıyla bir ilham almak için ustaca bir yoldur. Ancak notaya karşı, doğaçlama; portreye karşı, yaşayan model gibidir. İşaretlerin katılığını ilk duyguya dönüştürmek yorumcuya kalmıştır. [...] Bestecinin ilhamının notasyonla zorunlu olarak kaybettiğini, yorumcusu kendi başına geri getirmelidir (s. 15-16).

İlginçtir ki, Gould'a göre; "Müziğin, kitapların yüksek sesle okunması gerektiğinden daha fazla icra edilmesi gerekmez; çünkü mantı̆̆1, basılı sayfada mükemmel şekilde temsil edilir ve yorumcu [...] yorumlarının, müziği, yazılı olarak okuyamayacak kadar talihsiz bir izleyici için anlaşılır hale getirmesi dışında tamamen gereksizdir" (aktaran Bazzana, 1997, s. 20-21). Brahms da -neredeyse aynı yaklaşımla-, hiç kimsenin Don Giovanni'yi kendisi için doğru icra edemeyeceğini, eserin notasından, çok daha fazla keyif aldığını ifade eder (aktaran Swafford, 1998, s. 570).

Sabit notayı bu denli yücelten bu tür yaklaşımların yanında, "doğaçlamanın saflığı, sanatsal ilham odağından bir adım daha az uzaktır" (Hamilton, 2008, s. 195) türünden bakış açıları ise doğaçlamacı yorumculuğun, Barok Dönem'in ayrılmaz bir parçası olduğunu hatırlatmaktadır. Öyle ki J. S. Bach’a ilişkin ilk biyografinin yazarı olan Johann 
Nikolaus Forkel, Bach'ın doğaçlamacı yorumculuğunu, oğlu Wilhelm Friedemann Bach'ın gözünden şu cümlelerle aktarır:

Bu hayranlık uyandıran adamın org için yazdığı eserleri dahi, tapınma, ciddiyet ve asalet ifadeleriyle doludur; ancak, yazma sürecinde hiçbir şeyin eksilmediği, her şeyin doğrudan onun hayal gücünden canlandığı serbest org çal1şının daha dindar, daha ağırbaşlı, daha asil ve görkemli olduğu söyleniyor (Forkel, 1802, s. 18-19).

Kivy (2007), müzik tarihinin hangi yönlerinin müzik eserlerinin icrasıyla ilgili olabileceği konusunda bilgi sahibi olan "tarihsel açıdan bilgili/bilinçli icracı"dan (historically informed performer) söz eder: “Örneğin, Bach'ın İtalyan Konçertosu'nun tarihsel açıdan bilinçli bir performansı, Bach'ın zamanında eserin nasıl icra ediliyor olduğunu, Bach'ın, eseri ne maksatla icra ettiğini vs. bilen bir klavyecinin performansı olacaktır" (s. 93).

\section{Kesit 2: Anlatımcı Yorumculuk}

- W. A. Mozart, Figaro 'nun Düğ̈̈nü [Opera], KV 492, Perde II, Sahne 2, Cherubino: "Voi che sapete"

Mozart'ın ünlü operasından (1786) seçilmiş olan ariettanın sözlerine bakıldığında ve final metinlerinin aynı olduğu, dolayısıyla, "Voi che sapete che cosa è amor, / donne, vedete s'io l'ho nel cor" (Aşkın ne olduğunu bilen siz hanımlar, bakın benim kalbimde aşk var mı?) final cümlesinin, eserin henüz başlangıcında dahi söylenmiş olduğu görülmektedir. Bu noktada, şiirin ve müziğin formunun, bilinen bir yapının 'tekrarı' olarak algılanmasının ve sözlerin içeriğinin etki ağırlığının azalmasının önüne geçebilmek üzere, yorumcunun yaklaşımı önem kazanmaktadır.

Eserin, 1785 tarihli olduğu düşünülen otografı (Mozart, t.y., s. 175-181) incelendiğinde, bestecinin, soliste yönelik olarak söz konusu arietta boyunca yalnızca tek bir gürlük

4 Orijinal metnin tamami:

"Voi che sapete che cosa è amor, / donne, vedete s'io l'ho nel cor,

Quello ch'io provo vi ridirò, / è per me nuovo, capir nol so.

Sento un affetto pien di desir / ch'ora è diletto, ch'ora è martir.

Gelo e poi sento l'alma avvampar, / e in un momento torno a gelar.

Ricerco un bene fuori di me, / non so chi 'l tiene, non so cos'è.

Sospiro e gemo, senza voler, / palpito e tremor, senza saper.

Non trovo pace notte né di, / ma pur mi piace languir così.

Voi che sapete che cosa è amor, / donne, vedete s'io l'ho nel cor,

donne, vedete s'io l'ho nel cor, / donne, vedete s'io l'ho nel cor" (Mozart, 1999, s. 147-151). 
derecesi ifadesine yer vermiş olduğu görülmektedir: Solistin esere giriş noktasında, bas partisinde yer alan bir “pia.” [piano] (Mozart, t.y., s. 175).

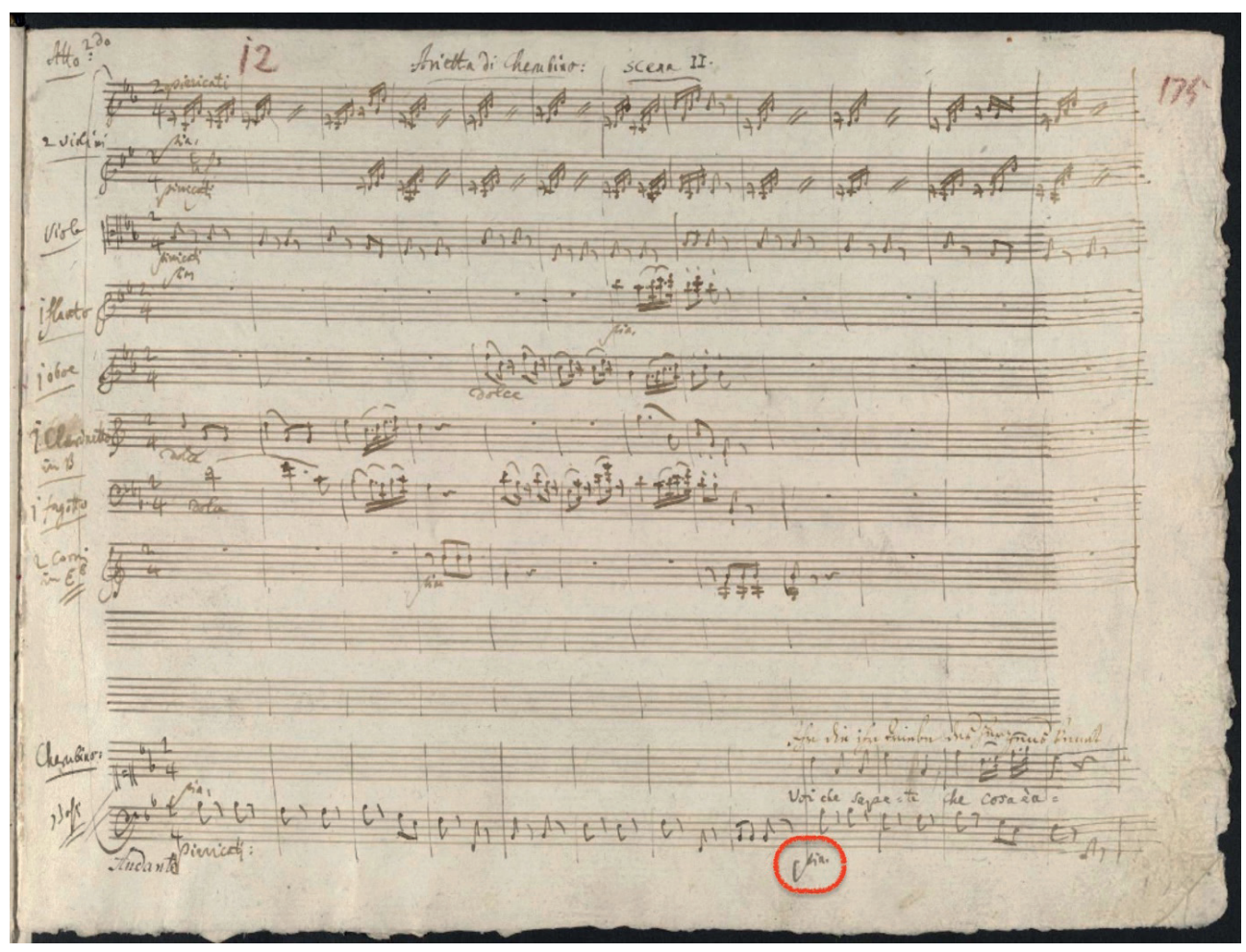

Örnek 2. W. A. Mozart, KV 492, II, 2, ö1-12 (Mozart, t.y., s. 175).

Parça boyunca notada görülen diğer terim ve kısaltmalar ise şu şekildedir:

- Andante (parçanın tümü için),

- pizzicati (yaylı çalgılar için),

- dolce (obua, klarinet ve fagot için),

- pia. (yaylı çalgılar, flüt ve korno için)

- $m f p$ [mezzoforte piano] (flüt ve obua için)

Parçada, bestecinin; orkestra için çeşitli gürlük, hız ve karakter ifadelerine yer verdiği halde, vokal partisi için, başlangıçtaki hafif gürlük derecesi (pia.) dışında herhangi bir yönlendirmeye gitmemiş olmasının yorumcu tarafından bir özgürlük alanı olarak görülmesi mümkündür ve bu noktada şiirin ve şiirdeki bölünmelerin önemi ön plana çıkmak- 
tadır. Fransız mezzo-soprano Catherine Trottmann'ın (2017) parçanın finalini nasıl yorumladığı incelendiğinde, kendisinin, eserin giriş ve final kısımlarını aynı vurgu ile ve üstelik, belirtilmiş olan $p$ derecesinden daha yüksek bir gürlükte (mezzopiano/mezzoforte) seslendirmiş olduğu anlaşılmaktadır (bkz. Tablo 1: QR Kod 3). Bu tür bir yaklaşımla, eserin finalinde aynı sözlerin art arda tekrarlanmasının bir önemi kalmamakta, 'sonsöz’ün altının çizilmesi için herhangi bir alan yaratılamamaktadır. Ne var ki, ariettanın ilk ve son sözlerinin benzerliği, İtalyan mezzo-soprano Cecilia Bartoli’nin yorumunda (Kabir, 2011) kritik bir yaklaşımla değer kazanmaktadır: Sözlerin tekrarlandığı kısımda, Bartoli, -başlangıçta, piano seviyesinde zaten söylenmiş olanı- bu kez çok daha hafif bir gürlükte, pianopianissimo ( $p p p$ ) seslendirmekte; şiiri, söz konusu 'hafiflikle' güçlendirmekte/vurgulamaktadır (bkz. Tablo 1: QR Kod 4):

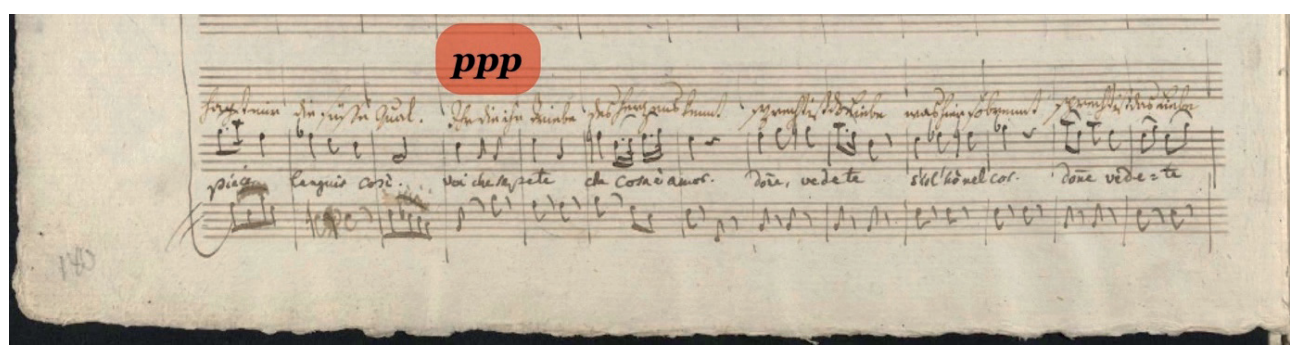

Örnek 3. W. A. Mozart, KV 492, II, 2, 0̈59-71: Otograf detayı; Cherubino ve bas partileri (Mozart, t.y., s. 180): C. Bartoli'nin, yorumu ile eklediği nüans.

Eserin odaklanılan noktasına ilişkin her iki yorum kaydının karşılaştırmalı spektrum görüntüsü şu şekildedir (2.1. Trottmann; 2.2. Bartoli): 


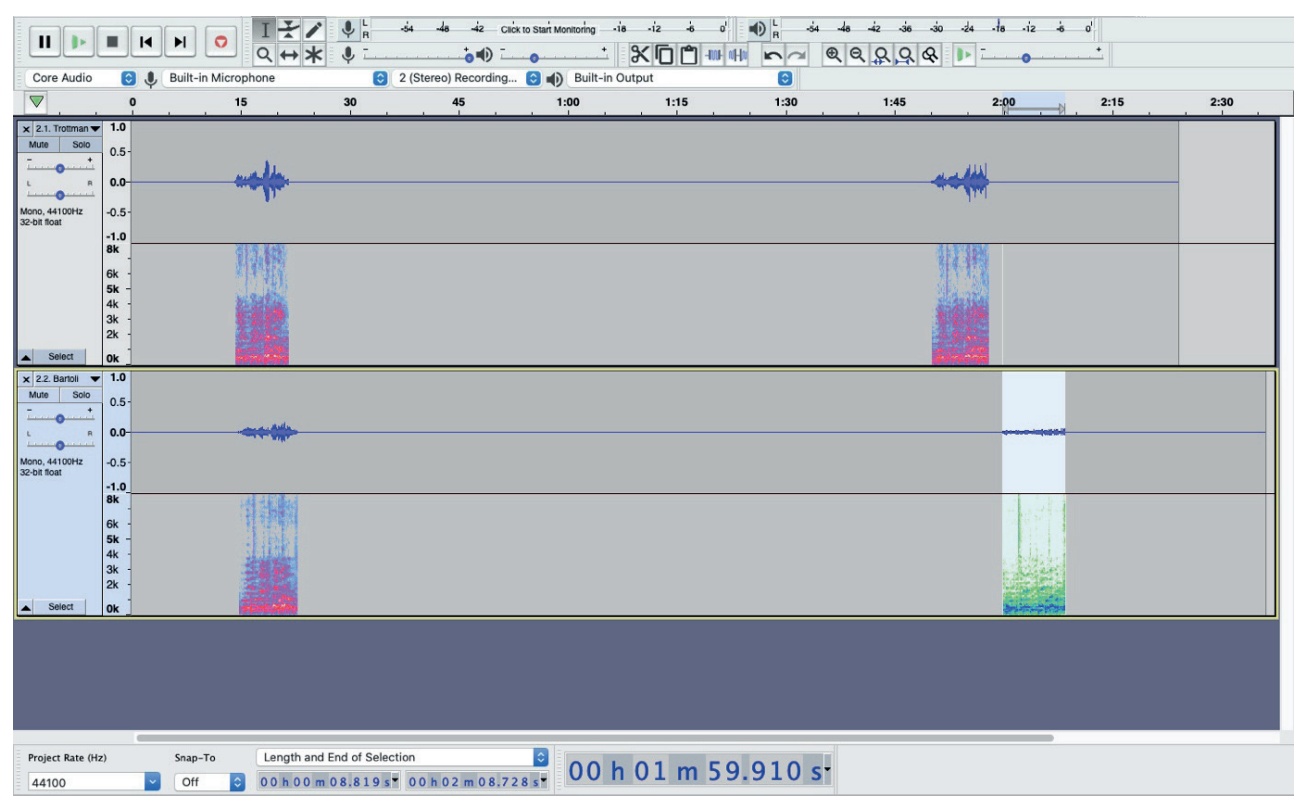

Şekil 2. W. A. Mozart, KV 492, II, 2, ö9-12; ö62-65: Karşılaştırmalı spektrum görüntüsü [Trottmann - Bartoli].

Şekilde, ariettanın başlangıç ve final kısımlarında aynı sözlerin sergilendiği ölçülerin spektrum görüntüleri bir arada vurgulanmıştır. Trottmann'ın söz konusu bölgelerdeki gürlük dereceleri neredeyse aynı iken, Bartoli'nin ikinci kısımda gürlüğü ne derecede düşürdüğü açıkça görülmektedir. Şekilde seçilmiş olan ölçü aralıkları için programın desibel cinsinden tespit ettiği gürlük dereceleri ise Bartoli’nin ariettaya katkısını nicel olarak gözler önüne sermektedir:

Tablo 2. W. A. Mozart, KV 492, II, 2, ö9-12; ö62-65: Karş1laştırmalı gürlük tablosu [Trottmann - Bartoli]

\begin{tabular}{|c|c|c|c|c|c|}
\hline \multirow[t]{2}{*}{ Yorumcu } & Eser & \multicolumn{2}{|c|}{ Kayit (d.sn.sl) } & \multirow{2}{*}{$\begin{array}{c}\text { Gürlük } \\
\text { (RMS dB) }\end{array}$} & \multirow{2}{*}{$\begin{array}{c}\text { Gürlük farkı } \\
\text { (RMS dB) }\end{array}$} \\
\hline & Ölçü & Başlangıç & Bitiş & & \\
\hline \multirow{2}{*}{ Trottmann } & $9-12$ & 00.13 .72 & 00.22 .41 & $-27.39 \mathrm{~dB}$ & \multirow{2}{*}{1.06} \\
\hline & $62-65$ & 01.49 .38 & 01.58 .93 & $-28.45 \mathrm{~dB}$ & \\
\hline \multirow{2}{*}{ Bartoli } & $9-12$ & 00.13 .23 & 00.24 .62 & $-33.83 \mathrm{~dB}$ & \multirow{2}{*}{6.79} \\
\hline & $62-65$ & 01.58 .19 & 02.10 .08 & $-40.62 \mathrm{~dB}$ & \\
\hline
\end{tabular}

Adorno (2003, s. 405), ifade unsurları olmadan müziğin de var olmadığını ve müzikte ifadesizliğin bile bir ifade haline geldiğini öne sürer. Hamilton (2008) da estetiğin, duygusal ve entelektüel olanın kaynaşması olduğunu ve biçimin, içeriğe atıfta bulunmadan 
söz konusu birleşim noktasına örnek teşkil edemeyeceğine (s. 89) dikkat çeker ve şu noktayı vurgular: "Bilindik bir eserin iyi prova edilmiş bir performansı, sonuçta, icracının daha önce seslendirdiği bir şeyi içereceğinden, etkisini gitgide kaybedecektir. Dolayısıyla, yorumcu, zaten bildiği, önceden var olan bir eseri seslendirmediği yanılsamasını veren doğaçlama tazelik/yenilik için çabalamalıdır” (s. 212).

"Müziksel kavrayış, estetik kavrayışın bir modeli/biçimidir: Doğru cümlelemeyi, doğru dinamikleri, doğru tempoyu bilinçli arayışta kendini gösterir. Ve dinleyici, hiç hata yapılmadığını onaylasa bile, doğru icrayı yanlış olandan ayırt eder" (Scruton, 2009, s. 37-38).

\section{Kesit 3: Kabul Edilebilir Yorumculuk}

- N. Rimski-Korsakov, Şehrazad [Senfonik Süit], Op. 35, IV. Bağdat’ta Festival - Deniz - Geminin, Bronz Atlı Heykelinin Bulunduğu Kayalıklara Çarpması

$\mathrm{Bu}$ kesiti incelerken, yorum estetiği konusunda başvurulabilecek bakış açılarından biri olarak Alman filozof Hans-Georg Gadamer'in (2009) felsefî hermeneutiğine değinmek yerinde olacaktır:

Yorum, eğer gerçekten metni konuşur duruma getirmek istiyorsa, doğru dilini keşfetmelidir. Fakat yine de tam da her yorumlama metnin bizatihi kendisiyle alakalı olduğu için, "kendinde/kendi başına" doğru hiçbir yorum olamaz. Geleneğin tarihsel hayatı, sürekli içselleştirilerek yorumlanmasına bağlıdır. 'Kendinde' doğru yorum, geleneğin doğasını yanlış anlayan aptalca bir ideal olabilir. Her yorumlama kendisini ait olduğu hermenoytik duruma uyarlamalıdır (s. 189).

Yorumlar, yorumculara göre değiştĭgi ve 'ufukların kaynaşması'nın ürünü olduğu için objektif olarak 'doğru yorum', Gadamer için ihtimal dâhilinde değildir (Hekman, 2012, s. 199). Herhangi bir yorumu, kendi bünyesi çerçevesinde doğru (veya yanlış) olarak nitelendirmenin mümkün olmayışının anlaşıldığı bu noktada, eserin kimliğine 'uygun' olan yorumun bir adım öne çıkarılabilmesi için ihtiyaç duyulan sıfat ise Amerikalı filozof Joseph Margolis tarafindan önerilmektedir: 'Makul' veya 'kabul edilebilir'.

"Eleştirmenin sözlerini, çabasının yorumlayıcı olduğu noktada basitçe doğru ya da yanlış, hatalı veya hatasız olarak yargılayamayız; ancak yorumunun, icracınınki gibi makul, mantıklı, kabul edilebilir, savunulamaz, mümkün vb. olduğunu gözlemleyebiliriz" (Mar- 
golis, 1965, s. 76) ${ }^{5}$. Bu açıdan denebilir ki, felsefî hermeneutikle ilişkili olarak ve estetik çerçevede değerlendirilmek üzere yorum, doğru ya da yanlış olarak değil, ancak 'makul' (kabul edilebilir) veya 'makul olmayan' (kabul edilemez) sıfatlarıyla nitelendirilebilir.

Felsefî hermeneutiğe göre performansın kabul edilebilir bir yorum kategorisinde ele al1nabilmesi için yorumun yaratıcılığının ve bu yaratının sahnelenmesinin de bir sınırı olması gerektiğini Thom (2006), 'temsil edilen şeye sadakat' olarak niteler: "Yorumlama yaratıcılık içerir. Yorum, nesneyi, yani eseri yeniden üretemez; ama temsil eder ve bu nedenle yorumlama, nesneye sadakat gerektirir" (s. 438).

Konuya ilişkin değerlendirme zeminini açıklayan bu ön bilgi ışığında, bu kesitte, Rimski-Korsakov'un Şehrazad'ının (1888) son bölümünden bir pasaja odaklanılmaktadır. Rus orkestra şefi Valery Gergiev'in 2005 tarihli yorumunun (Jose, 2012) (bkz. Tablo 1: QR Kod 5), felsefî hermeneutik bağlamında gerek notaya (Rimski-Korsakov, 1956) sadakatiyle gerekse eserin metinsel kurgusunu ön planda tutan yaklaşımıyla 'kabul edilebilir bir yorum’ olduğu şüphe götürmemektedir.

Aynı kesitin oldukça sıra dışı bir yorumu ise Finli şef Leif Segerstam tarafından (SinfonicadeGalicia, 2015) (bkz. Tablo 1: QR Kod 6) 15 Mayıs 2015 günü sergilenmiştir:

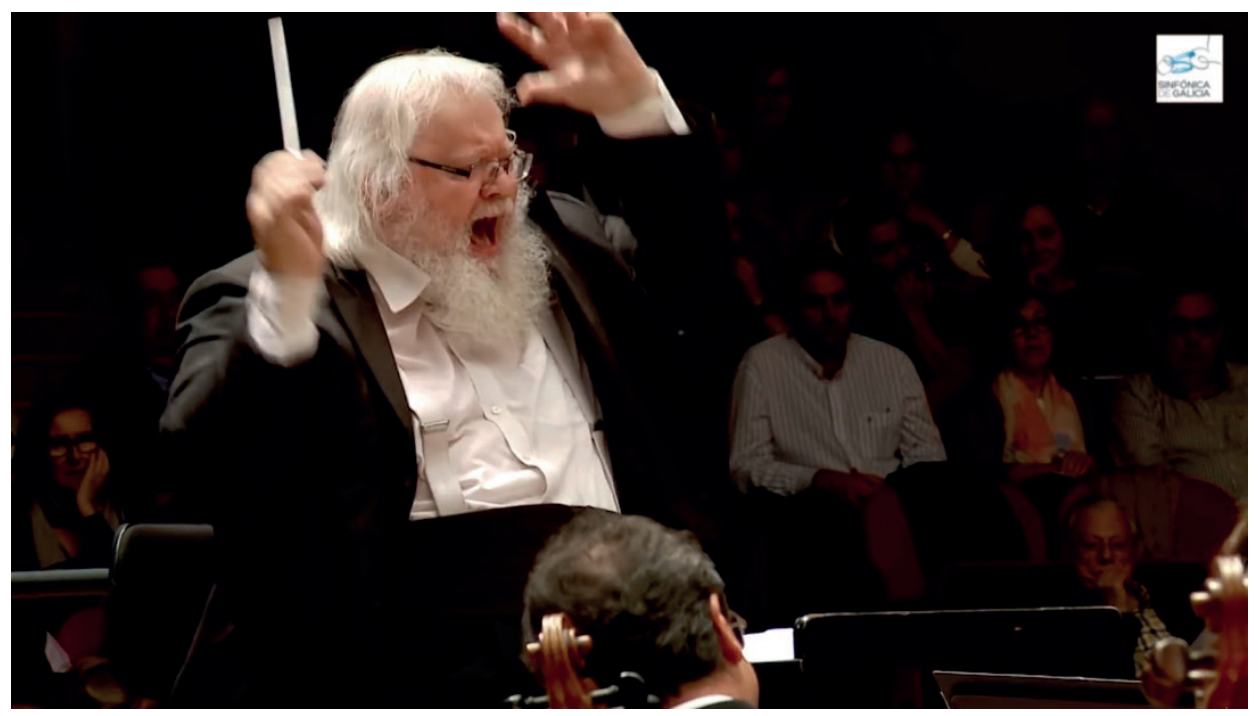

Şekil 3. N. Rimski-Korsakov, Op. 35, IV: Yorum detayı; Segerstam (SinfonicadeGalicia, 2015).

5 Yazarın, 'doğru’ ile 'makul' kavramları arasındaki ilişki ve ayrıma dair açıklamaları için bkz. Margolis, 1965, s. 85-94; 1992, s. 43-45. 
Bir hikayesi olan ve doğru anlaşılmayı talep eden 'program müziği' türüne örnek bu eserin Segerstam yorumunun, hermeneutik açıdan kabul edilebilirliği tartışmalı bir noktada konumlanmaktadır ${ }^{6}$. Eserin -kendi içinde üç alt başlıktan oluşan son bölümününilgili kesiti; geminin, bronz atlı heykelinin bulunduğu kayalıklara çarpmasına (Aktüze, 2007, s. 1893) müziksel bir kompozisyonla sahne olmaktadır ve bu pasaj için uygun görülen ifadeler nota üzerinde (Rimski-Korsakov, 1956, s. 106-112) besteci tarafindan açıkça belirtilmiştir: Kesitin başlangıcında (ö496) $p$ (piano) gürlük derecesiyle birlikte yer alan Più stretto terimi, -aynı ritimde, sesleri- 'biraz daha sıkıştırarak' anlamına gelmekte ${ }^{7}$; söz konusu 'sıra dışı'lığın gerçekleştiği kısmın başlangıcında (ö540) ff (fortissimo) gürlükle birlikte görülen Spiritoso ise bölmenin 'canlı ve hareketli bir karakterde' yorumlanması gerektiğine işaret etmektedir.

Bestecinin bu kısım için tasarladığı anlatımın hayli dışında bir yorumla eseri dinleyiciyle buluşturan Segerstam'in kendisinin ve -üflemeli çalgılar dışındaki- orkestra üyelerinin savaş veya bir enkaz sahnesini canlandırmak üzere 'bağırışları' müziğin önüne geçmekte, temayı ayırt edilemez hale getirmektedir. Gülümseyen yüz ifadelerine bakıldığında, dinleyici kitle bir tarafa, orkestra açısından dahi eserin dramatik metni ile olan bağın yorum yoluyla zedelenmiş olduğu açıkça görülmektedir:

6 Program müziği kavramı ile felsefî hermeneutiği çeşitli örnekler üzerinden ilişkilendiren bir çalışma için bkz. Karadeniz, 2020a.

7 Stretto terimi kimi zaman accelerando anlamında, hızın artırılması amacıyla da kullanılır (Bennett, 1995, s. 317). O derece ki Brossard (1705), terimi vuruşların sıklaştırılmasına atfen Largo'nun zıddı (s. 116) olarak tanımlamakla kalmayıp Presto ile de neredeyse eş değer tutar (s. 179). 


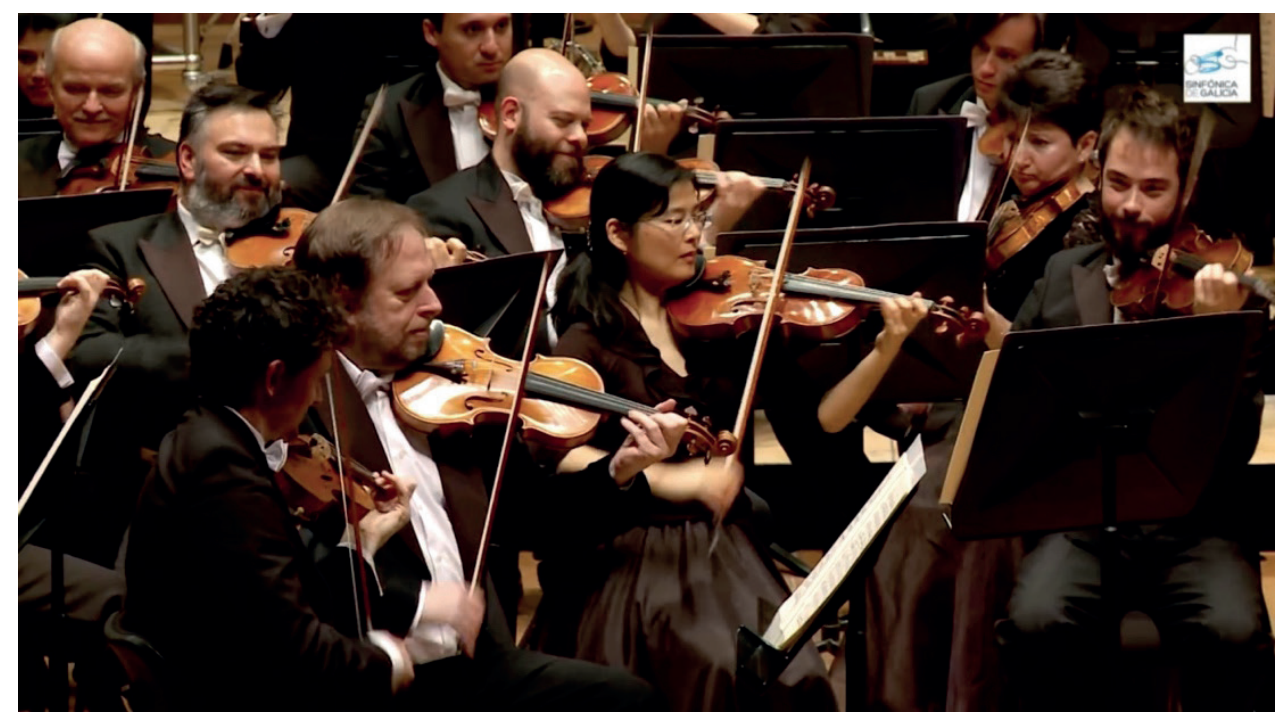

Şekil 4. N. Rimski-Korsakov, Op. 35, IV: Yorum detayı; Sinfónica de Galicia Orkestrası (SinfonicadeGalicia, 2015).

“Shakespeare'in büyüklüğü, kaynağını 'gerçek' ağlamakta değil, ağlamanın doğru, kapsamlı biçimde yansıtılmasında bulur” (Lukács, 1999, s. 256). Her ne kadar Klasik Dönem'in 'yapı' vurgusu, 'müziksel' anlamları ve 'soyut' eğilimleri, Romantik Dönem'de 'ifade' vurgusu, 'müzik-dışı' anlam ve daha 'somut' anlatımlara karşılık gelmekte ise de (Agawu, 1991, s. 135), Segerstam'in şefliğinde sergilenen böylesi bir yaklaşım, eseri kısmen gölgede bırakması sebebiyle, yorumu, kabul edilebilirliği tartışmalı bir noktaya taşımaktadır. Gadamerci çerçeveden bakıldığında, anlatımda -birinci derecede olmasa da- eser sahibinin rolü bulunmaktadır ve bu rol, yazılı esere sadakat noktasında belirleyicidir.

Şarkıcının ses rengi, vibratosu ve glissandoları, piyanoda pedal ve dokunma teknikleri, yaylı çalgılarda yayın kullanış tarzındaki ince ayrımlar ve orkestra yönetmeninin hem teknik hem de ruhbilimsel yönden topluluk üzerinde kurduğu egemenlik, bu [yorumcunun kişiliği ve teknik donanımının yol açtığı] etkilerin başlıcalarıdır. Böyle her seslendirmede yapıt, değişik nitelikler kazanmaktadır. [...] Her şeyden önce yapılan seslendirmeyi bestecinin onaylayıp onaylamayacağı sorusu üzerinde durulmaktadır (Kütahyalı, 1996, s. 12). 
Konu edilen yorumun, 'ilginçliği' dolayısıyla ayrı bir değeri hak ettiği de elbette savunulabilir. Bu noktada, Stuart Hampshire ve Monroe C. Beardsley'in yaklaşımları önem arz eder. Bazı yorumların "katlanılamaz, saçma, uydurma, zorlama, yapmacık veya yakışıksız olduğu halde, yine de aydınlatıcı, olası, özgün ve ilginç" gibi övgü sıfatları ile değerlendirilebileceğini ifade eden Hampshire (1966, s. 108) ve bu fikri geliştiren Beardsley (1970, s. 40-42), kesitin bu türlü yorumlanışına da bir değer atfedebilecek eleştirmenlere dikkat çeker. Ancak bu çalışmada, eser ile kişi arasındaki ‘doğru anlama'yı merkeze alan hermeneutik felsefe çerçevesinde kalınarak yorumun kabul edilebilirliği noktasına odaklanıldığından, bu 'diğer' yaklaşım(lar)a bu şekilde yalnızca değinilmekle yetinilmiştir. "Göze göre bir nesne, kulağa göre olduğundan farklı gelir; ve gözün nesnesi, kulağınkinden farklı bir nesnedir" (Marx, 1968, s. 541). Dolayısıyla, bir çeşit yansıtma kaygısı güden bu tür bir yorumun, hermeneutik açıdan, yine müziğin araçlarıyla biçimlenmesi ve bu yolla ses ile görüntü arasındaki farklılaşmanın olabildiğince önüne geçilmesi beklenir.

\section{Kesit 4: Entelektüel Yorumculuk}

- A. A. Saygun, Yunus Emre [Oratoryo], Op. 26, Bölüm I, No. 2, Recitativo: “Yalancl dünyaya konup göçenler"

Ahmed Adnan Saygun'un Yunus Emre başlıklı oratoryosunun (1942), tenor solo, timpani ve yaylı çalgılar için resitatifi "Yalancı dünyaya konup göçenler", entelektüel bir yoruma olanak tanıması açısından incelemeye değer bir örnektir.

Çalışmada, koşma biçimindeki şiirin tekrarlanan mısraı olan "Ne söylerler ne bir haber verirler" cümlesinin, ö13-15 arasında ikinci kez sunulduğu kısma odaklanılmıştır. Tenor Erol Uras'in 1991 tarihli yorumu (Dal, 2017) söz konusu resitatifin makul bir icrası olarak arşivlerdeki yerini almıştır (bkz. Tablo 1: QR Kod 7).

Örnek 4'teki notada, yalnız dört farklı sesten (do-si b -la-sol) oluştuğu görülen bu müzik cümlesinin yer aldığı resitatifin tamamında, geleneksel Türk müziğinin Karcığar makamı ses organizasyonu soyutlanmaktadır ${ }^{9}$. Dolayısıyla, geleneksel müzik ile olan ilişkisi

8 İncelenen resitatifin tamamı:

"Yalancı dünyaya konup göçenler / Ne söylerler ne bir haber verirler

Üzerinde türlü otlar bitenler / Ne söylerler ne bir haber verirler.

Kimisinin üstünde biter otlar / Kiminin başında siraserviler

Kimi mâsûm kimi güzel yiğitler / Ne söylerler ne bir haber verirler" (Saygun, 1946, s. 13).

9 Bestecinin, aralarında bu makamın da bulunduğu çeşitli soyutlama yaklaşımları için bkz. Karadeniz, 2020 b. 
açık olan bu pasajın yorumunda söz konusu makamsal geleneğin 'izlerine’ yer vermenin, eserin temsilini güçlendireceği düşünülebilir.

Türk halk müziği geleneğine de hâkim bir tenor olan Ömer Yılmaz'ın, 2005 tarihli yorumu (Saygun, 2007, parça 7; Akkuş, 2008), tam olarak bu yaklaşımın bir ürünüdür. Yılmaz, odaklanılan müzik cümlesinin sonuna, biri -klasik Batı müziği ses sisteminde karş1lı̆̆1 olmayan-Segâh perdesi olmak üzere iki küçük çarpma sesi ekleyerek Çağdaş Türk Müziği örneği olan eserin gelenek ile bağlantısını vurgulamış ve kompozisyonun söz ile uyumunun kendi üslûbunca altını çizmiştir (bkz. Tablo 1: QR Kod 8):

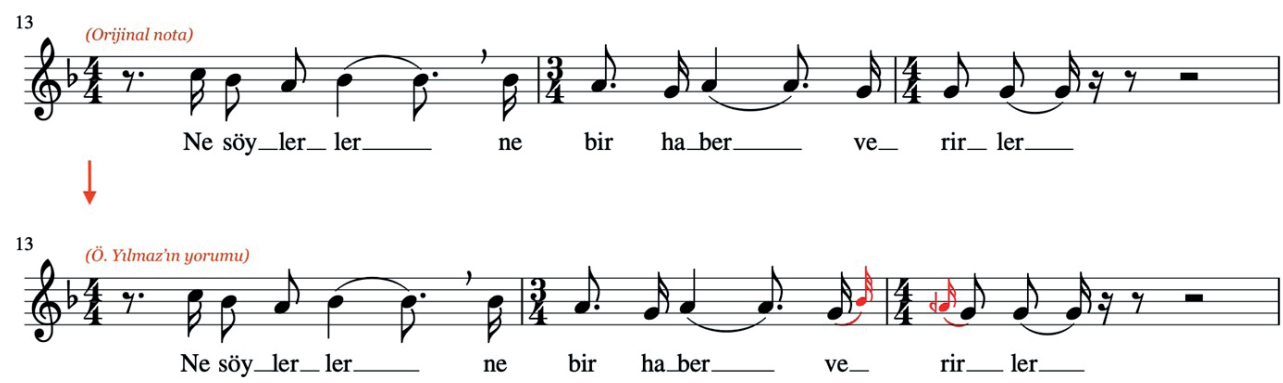

Örnek 4. A. A. Saygun, Op. 26, I, 2, ö13-15 (Saygun, 1969, s. 20): Ö. Yılmaz’ın, yorumu ile eklediği sesler.

Her iki yorumcunun, söz konusu noktadaki seslerinin frekans değerleri, anılan yorum farkını açıkça ortaya koymaktadır. Erol Uras'ın, ö14'ün sonundan itibaren (verirler sözcüğ̈̈) notaya sadık kalarak, -12 eşit aralıklı tampere sisteme göre $392 \mathrm{~Hz}$ değerindeki$\mathrm{sol}_{4}$ sesini koruduğu görülmektedir: 


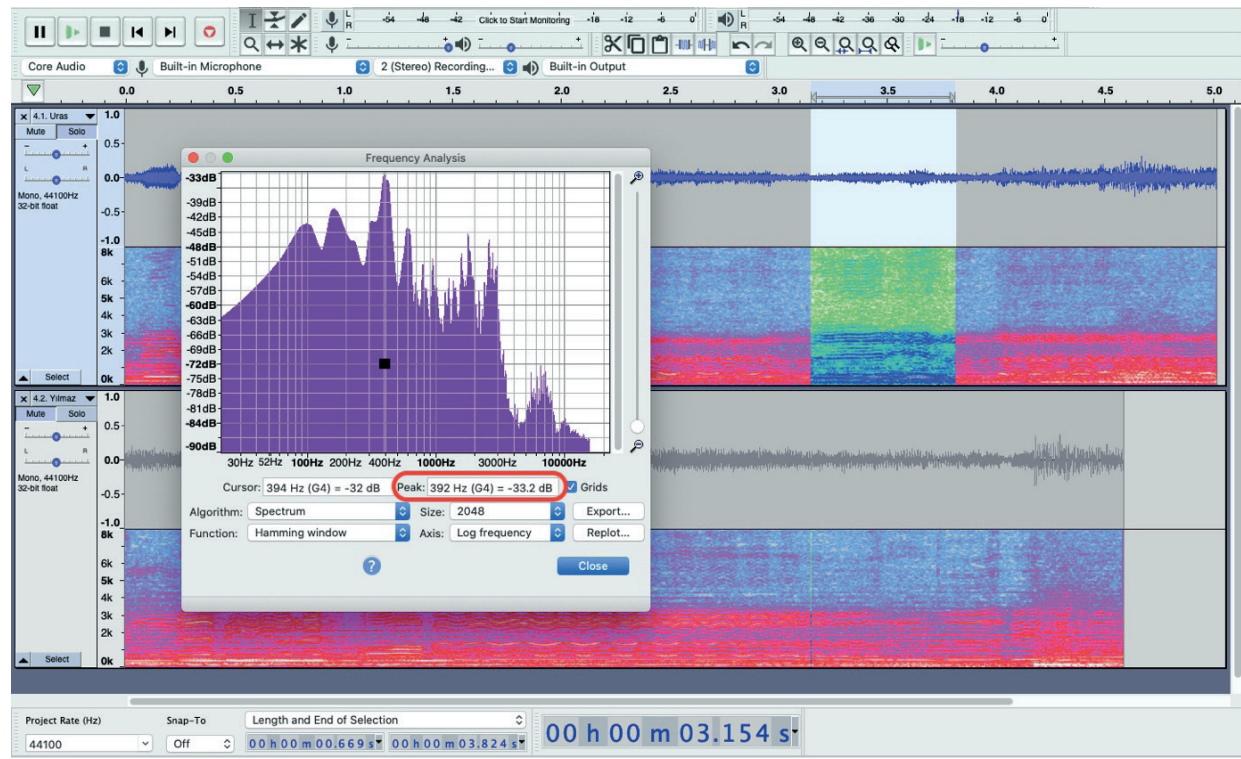

Şekil 5. A. A. Saygun, Op. 26, I, 2, ö14-15: Spektrum görüntüsü ve frekans analizi [Uras].

Bunun yanında, Ömer Y1lmaz'ın ö15'e eklediği sesin (verirler sözcüğ̈̈, 2. hece) frekans değeri ise $422 \mathrm{~Hz}$ olarak tespit edilmiştir:

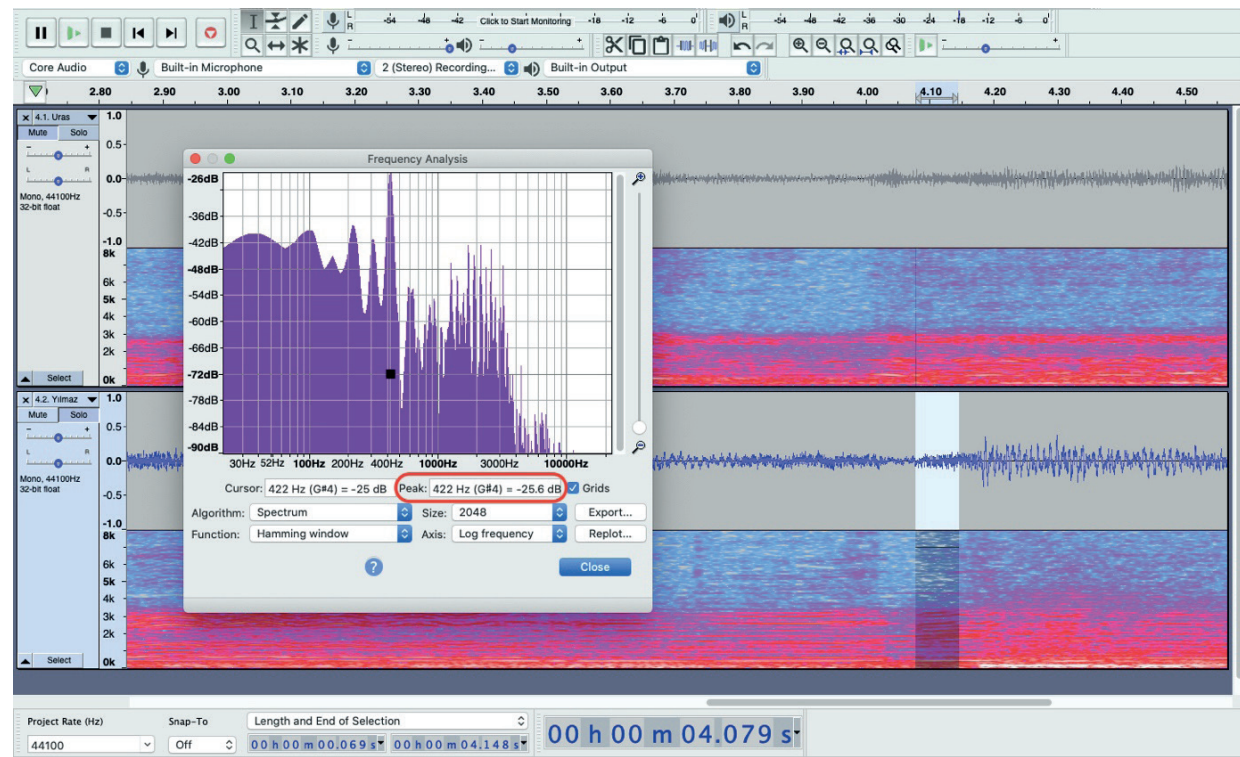

Şekil 6. A. A. Saygun, Op. 26, I, 2, ö15: Spektrum görüntüsü ve frekans analizi [Yılmaz]. 
Saptanan frekansın, 12 eşit aralıklı tampere sistemde yeri bulunmamakta, karşı1lığı söz konusu makamsal yapı ile anlam kazanmaktadır: Karar ses olan Dügâh perdesi $\left(\mathrm{sol}_{4}\right)$ ile makam dizisinin ikinci derecesi olan Segâh perdesi arasındaki frekans oranı, Töre-Karadeniz sisteminde 1/1,096 olarak belirtilmiştir (Karadeniz, t.y., s. 100). Dolayısıyla eklenen perdenin değeri $429 \mathrm{~Hz}$ civarında olmalıdır ki bu değerin, programın tespit ettiği değere $(422 \mathrm{~Hz})$, tampere sistemin gerektirdiği ikinci derece değerinden $\left(\mathrm{la}_{4}=440 \mathrm{~Hz}\right)$ daha yakın olduğu açıktır.

Önceki kesitle de ilişkili olarak, akla, bu tür bir 'ses ekleme'nin besteci açısından kabul edilebilir olup olmadığı hususunda bir soru gelebilir. Bu noktada, Saygun'un bu türde yorumlara olanak tanıyan bir besteci olduğuna dikkat çekmek ve kendisinin, geleneksel müziğe ilişkin perde, çalg1 vb. somut öğelere, eserlerinde simgesel olarak yer verdiğini hatırlamak gerekir. Bunlara örnek olarak, Yunus Emre'de geçen (Bölüm I, No. 4, Aria) flüt solosunun sembolize ettiği 'ney' ${ }^{10}$ ile bestecinin Kerem başlıklı operasında (Op. 28) sahnede görünen -ancak orkestra çalgıları arasında olmayan- 'bağlama' verilebilir. Asıl dikkat çekici nokta ise şudur ki, Kerem'de:

Orkestra eşliğinde, söz konusu ara perdelerin 12 eşit aralıklı Batı müziği ses sistemine göre seslendirilmesini zorunlu k1lacak bir yönlendirme yoksa, vokal partisinde bu perdeler, halk müziğinde kullanıldığı nitelikleriyle yer alabilmektedir. Bu yaklaşım, yorumcuya atfedilebileceği kadar, -buna sağladığ 1 imkândan ötürü- bestecinin yaklaşımı olarak değerlendirilmelidir (Karadeniz, 2018, s. 222).

Dolayısıyla, benzer bir zeminin Yunus Emre için de geçerli olduğunu ve Yılmaz'ın bu zemine özellikle 1şık tuttuğunu söylemek mümkündür ${ }^{11}$. Bestecinin soyutlama yoluyla gizlediği bu makamsal yapı, Yılmaz tarafından dinleyiciye, eklenen ses ve tavır sayesinde bir nebze görünür/işitilir k1lınmıştır; bu sebepledir ki söz konusu yorum, eseri 'anlama' (entelekt) ile başlayan bu sürecin entelektüel bir ürünüdür. Teorik bir art alanın eserin yorumundaki rolünü ortaya koyan bu örnek, 'eserin performansının incelenmesi' ile 'eserin incelenmesi’ arasındaki görünmez bağın da ispatı niteliğindedir.

10 Bestecinin bu noktadaki yaklaşımı yalnızca sembolizasyonla sınırlı kalmamıştır. Notada (Saygun, 1969, s. 3344) bu partinin "Ney ossia Flauto" (ney veya flüt), ve aynı parçadaki vurmalı çalgı partisinin de "Kudüm ossia Timpani” (kudüm veya timpani) için yazıldığı açıkça belirtilmiştir.

11 Aynı yaklaşımı Kerem performansıyla Erol Uras da sergilemiştir. Bkz. Karadeniz, 2018. 
Hamilton (2008), ses ve dinamik gibi çeşitli parametreleri içeren bu denli küçük ölçekli yorum dokunuşlarına "mikro özgürlük" (micro-freedom) adını verir (s. 212). Collingwood (1958) ise bu tür yorumcuları, eserin -yeniden- üretiminde besteci kadar etkin, sanatsal bir "işbirlikçi”" (collaborator) olarak tanımlar (s. 320-321).

Goulish (2005); partisyonun, verilen bir pasajın alanını (sınırlarını) ve zamansal bölünümünü gösterdiğini, ancak duyulan gerçek seslerin, icracının müziksel duruma verdiği karşılıktan gelmesi gerekliliğini (s. 183) ifade eder ${ }^{12}$. Bu şekilde yaratılan doğallığı ise şöyle tasvir eder: "Kişi, sanki dinlemiyor da doğadaki bir şeye bakıyor gibi dinler" (s. 184). Lukács (1999) da Estetik'inde, aynı ilgi çekici doğallığı, felsefî açıdan şu cümlelerle yorumlar: "Eski halk şarkılarının, karşısında haklı bir hayranlık duyduğumuz, örnek saydığımız yalıngüzelliğinin kaynağı, çok daha gelişmiş bir evrededir; bu evrede tümce, bağlam -kavramsalgenelleştirme açısından gelişmenin doruğuna varmış- sözcüğe egemendir ve kapsamlı özyapısından ötürü şiirsel, renklemeli (pitoresk) etkiler yaratır" (s. 145).

Şurası bir gerçektir ki icracının ilk görevi, kabul edilebilir bir performans için gerek şart olan notaya uyum/itaate özen göstermektir ${ }^{13}$ ve bu şartın yerine getirilmesinin ardından, yorumcuya, performans pratiğinin sınırları dâhilinde kendi zevkini, müziksel muhakemesini ve yaratıcılığını kullanmakta özgür olduğu büyük bir belirsizlik alanı kalır (Kivy, 2007, s. 100-101). İşte bu alan içerisinde hata olarak değerlendirilebilecek tüm parametreler dışarıda bırakıldığında geriye kalan -ve sınırları belirsiz olduğu için- sonsuz yaklaşımın her birinin birer yorum değeri mevcuttur.

\section{Sonuç ve Değerlendirme}

Müzik performansı analizi, eserlerin farklı yorumlarının temelinin yorumcular tarafindan ne derecede sağlam kurulduğuyla doğrudan ilgilenmesi dolayısıyla, müzik teorisi ile iç içe bir çalışma zeminine sahiptir. Şüphesiz bu çalışmada ele alınan her bir yorum, eserin farklı noktalarını aydınlatan değerli birer icra örneğidir. Ancak bu ve benzeri icralardan bazılarının estetik seviyesinin, dinleyici açısından hangi noktada fark yarattığının açıklaması, çalı̧̧ma boyunca birkaçına odaklanılan sayısız detayda gizlidir. Söz konusu

12 Yazar bu ifadesini Amerikalı avangart besteci Morton Feldman'ın (1926-1987) solo viyolonsel için Projection 1 başlıklı eserinin (1950) 'grafik notasyonu' için kullanmakta ise de yaklaşımını düşünsel olarak, çalışmanın ilgili kesiti çerçevesine genellemek mümkündür.

13 'Nota uyumu’ konusu için bkz. Goodman, 1968, s. 143-148. 
detaylar ise -etimolojik olarak, bir şey 'yapma'nın aksine bir 'düşünme eylemi' olan (Palisca, 1980, s. 741)- 'teori’nin konusudur.

Çalışmada incelenen kesitlerin şu şekilde değerlendirilmesi mümkündür:

- Kesit 1'de; J. S. Bach'ın keman ve klavsen için 3 numaralı sonatının (BWV 1016) üçüncü bölümü, piyanist Glenn Gould'un, Barok Dönem’i yansıtan 'doğaçlamacı yorumculuk' yaklaşımıyla yeniden şekillenmektedir. Gould, hemen ilk ölçülerde, Barok anlayışının beraberinde getirdiği ufak bir kırık akor işareti ( $\zeta$ ) eklemesi ile dönemin, notayı esneterek süsleme tavrına yaklaşmakla kalmamış, ilerleyen ölçülerde gelecek olan ezgisel hareket ile de bütünlük sağlayan bir katkı sunmuştur. Bu noktada, anılan katkının bizzat yorumcunun birikimi ile destekleniyor olması ise ayrı bir öneme sahiptir. Böylece, yorumcunun özgürlüğünün dayanaksız bir serbestlik anlamına gelmediği, doğrudan, performansın -doğaçlamacı- yorumcusu tarafından ortaya konmaktadır ki bu dayanağın sunulması, yorumcu-icracı ayrımında gözetilen temel kriterlerden de biridir.

- Kesit 2; W. A. Mozart'1n Figaro ’nun Dügüüü’nden (KV 492) seçilen arietta üzerinden, mezzo-soprano Cecilia Bartoli’nin 'anlatımcı yorumculuk' yaklaşımına sahne olmaktadır. Yorumcu, ariettanın sonlarına eklediği bir nüans ile ( $p p p)$, karakterin (Cherubino) ihtiyacı olan dramatik anlatımı, zıtlıkla, sönerek vurgulamıştır. Yapılan eklemenin yine piano $(p)$ gürlük skalasında olması dolayısıyla notaya sadakati de önemseyen bu teatral vurgu, müzik-dışı içeriğin müziğe uygun eklemlenmesi, müzikle örtüştürülmesi noktasında özel bir yorumdur. Otografta soliste yönelik herhangi bir gürlük derecesi değişiminin yer almaması, elbette -döneminde, söz konusu vokal partinin ne şekilde seslendirileceğinin solist tarafından zaten biliniyor oluşunun yanında- besteci tarafından sunulmuş bir serbestlik alanı olarak değerlendirilebilir. Ancak bu kesit göstermektedir ki; söz konusu serbestliğin, solistin ya da performansın değil, doğrudan eserin, karakterin ve anlatımının hizmetinde kullanılması; bir başka deyişle, anlatımın, tekniğe feda edilmemesi, sanat eserinin 'dönüştürücü’ etkisi için uygun zeminin teşkilinde kritik rol oynamıştır.

- Kesit 3 'te; Rimski-Korsakov'un Şehrazad'ının (Op. 35) son bölümünün Valery Gergiev ve Leif Segerstam yorumları, 'kabul edilebilir yorumculuk' zemininde karşılaştırılmıştır. Segerstam'in dış seslerle eklemekten kaçınmadığg teatral sahnenin, -önceki kesite benzer şekilde- anlatımın güçlendirilmesine yönelik bir yaklaşım olarak değerlendirilmesi ilk bakışta mümkün görünse de müziğin önüne geçen marjinal niteliği sebebiyle, felsefî hermeneutiğe göre kabul edilebilir olmaktan uzaktır. Doğası gereği 
doğru anlaşılmayı talep eden 'program müziği' örneği olan eserde, metin, sadık kalınmas1 gereken bir ikinci alan olarak müzik kompozisyonun daima (bir madalyon gibi) diğer yüzündedir. Bu bağlamda, bu türde eserlerin, yorumcuyu bir kat daha fazla sınırlamakta olduğu çıkarımı yapılabilirse de felsefî hermeneutiğin açıkladığı üzere, bu sınırlılık bir dezavantaj değildir. Rimski-Korsakov'un ve (anlatıcı karakter) Şehrazad'ın aktardığı metinleri birlikte aydınlatan ve müziğin içinde kalarak ürettiği yorumunu notada belirtilen yönlendirmeler çerçevesinde şekillendiren Gergiev, kompozisyonu, hermeneutik aç1dan uygun bir yolla anlamış ve anlatmıştır.

- Kesit 4; Saygun'un oratoryosu Yunus Emre'den (Op. 26), çalışma kapsamında 'entelektüel’ olarak nitelenen bir yorumculuk örneği içermektedir. Tenor Ömer Yılmaz, resitatifin cümle sonlarına eklediği iki küçük çarpma sesi ile -ki bunlardan biri mikrotonal aralık oluşturmakta-; dönemin Ulusalcılık akımının, Çağdaş Türk Müziği’nin ana materyalinin ve eserin bünyesindeki Türk Halk Müziği tavrının bilincinde bir yorum sunmuştur. Bu örnekle birlikte, müzik performansı analizinde 'bestecilik yaklaşımı' konusunun yadsınmaması gerektiği vurgulanmıştır. Saygun stilinin önemli eksenlerinden biri olan makamsal soyutlamayı yorumuna yansıtan Yılmaz'ın halk müziği geleneği birikiminin beraberinde getirdiği bu doğal performans, esere sadakatin üzerinde, eserin sunduğu imkânı kullanarak onu bir adım ileri taşıyabilmiş bir yorum olma özelliğine sahiptir.

Özellikle farklı yüzyıllardan seçilmiş eserleri içeren bu repertuvar, çağımız özgün yorumcusunun özgürlük/serbestlik/yaratıc1lığında, tarihsel, kültürel ve içeriksel bağlamın belirleyiciliğine dikkat çekmektedir. Performansın analizi ile eserin analizi arasındaki, her iki yöne de katk1 sağlayan bağı ve bu iki analitik düzlemin kesişiminden doğan yorumların niteliklerini aydınlatmak amacıyla ele alınmış olan tüm bu örneklerin ortak özelliği ise şudur: Kesitlerde öne çıkarılmış olan detayların tamamı, anlık katkı veya hata olarak değerlendirilmesi mümkün olmayan, düşünülmüş ve estetik kaygı ile üretilmiş 'rafine' eklemelerdir. Bunun yanı sıra şu nokta da ilginçtir ki olumlu ve olumsuz yöndeki her bir uç örnek, deyim yerindeyse 'en yaratıcı' ve ‘en kabul edilemez' her bir yorum, notaya olan sadakatin esnetilmesi yoluyla gerçekleștirilmiştir. Bu sonuç da performans ile yazılı eser (nota) arasındaki adımlarını takip ettiğimiz özne olan yorumcunun ne tür bir 'gri alanda' hareket ettiğini ortaya koymaktadır. 
Hakem Değerlendirmesi: Dış bağımsız.

Çıkar Çatışması: Yazar çıkar çatışması bildirmemiştir.

Finansal Destek: Yazar bu çalışma için finansal destek almadığını beyan etmiş̧ir.

Peer-review: Externally peer-reviewed.

Conflict of Interest: The author has no conflict of interest to declare.

Grant Support: The author declared that this study has received no financial support.

\section{Kaynakça/References}

Adorno, T. (2003). Music, language and composition (S. Gillespie, Çev.). The Musical Quarterly, 77(3), 401-414.

Akkuş, T. (2008, 15 Mayıs). Yunus Emre Oratoryosu Recitativo Omer Yılmaz [Video]. Erişim adresi: https://youtu. be/tWisy50UpKY?t=70

Aktüze, İ. (2007). Müziği okumak: Cilt 4. İstanbul: Pan Yayıncılık.

Bach, J. S. (t.y.). 6 Violin sonatas: Sonata in e major, BWV 1016 [Nota]. Erişim adresi: https://ks4.imslp.info/files/ imglnks/usimg/e/ee/IMSLP396114-PMLP05971-D-B_Mus._ms._Bach_P_229_(3)(BWV_1016).pdf

Bach, J. S. (1994). Sonata no. 3 in e major, BWV 1016, III. Adagio ma non tanto. [J. Laredo ve G. Gould tarafindan]. The Glenn Gould edition - Bach - sonatas for violin \& harpsichord, BWV 1014-1019 / sonatas for viola da gamba \& harpisichord, BWV 1027-1029 (2 CD): CD 1 [CD] içinde. New York: Sony Classical. (1975)

Bach, J. S. (2012). Violin sonata no. 3, BWV 1016, III. Adagio ma non tanto. [L. Kogan ve K. Richter tarafindan]. Johann Sebastian Bach - 6 sonaten für violine und cembalo, BWV 1014-1019 (2 CD): CD 1 [CD] içinde. Japan: Denon. (1972)

Bazzana, K. (1997). Glenn Gould: The performer in the work: A study in performance practice. New York: Oxford University Press.

Beardsley, M. C. (1970). The possibility of criticism. Detroit: Wayne State University Press.

Bennett, R. (1995). Music dictionary. New York: Cambridge University Press.

Bowen, J. A. (2001). Finding the music in musicology: Performance history and musical works. N. Cook ve M. Everist (Ed.), Rethinking music (s. 424-451) içinde. New York: Oxford University Press.

Brossard, S. de (1705). Dictionaire de musique: Contenant une explication des termes grecs, latins, italiens, \& françois, les plus usitez dans la musique. Paris: Chez C. Ballard. Erişim adresi: https://www.loc.gov/ item/39019786/

Bujić, B. (2002). Criticism of music. A. Latham (Ed.), The Oxford companion to music (s. 324-326) içinde. New York: Oxford University Press.

Busoni, F. (1911). Sketch of a new esthetic of music (T. Baker, Çev.). New York: G. Schirmer.

Calvocoressi, M.-D. (1923). Towards a method in musical criticism. The Musical Quarterly, 9(1), 72-81. Erişim adresi: https://www.jstor.org/stable/738544

Collingwood, R. G. (1958). The principles of art. London \& New York: Oxford University Press.

Dal, M. (2017, 2 Mart). Ahmed Adnan Saygun - Yunus Emre Oratoryosu op: 26 [Video]. Erişim adresi: https:// youtu.be/Xctk3cjoDZY?t=357

Everist, M. (2001). Reception theories, canonic discourses, and musical value. N. Cook ve M. Everist (Ed.), Rethinking music (s. 378-402) içinde. New York: Oxford University Press. 
Forkel, J. N. (1802). Ueber Johann Sebastian Bachs leben, kunst und kunstwerke. Leipzig: Hoffmeister und Kühnel. Gadamer, H.-G. (2008). Hakikat ve yöntem: Birinci cilt (H. Arslan ve İ. Yavuzcan, Çev.). İstanbul: Paradigma Yayıncılık. Gadamer, H.-G. (2009). Hakikat ve yöntem: İkinci cilt (H. Arslan ve İ. Yavuzcan, Çev.). İstanbul: Paradigma Yayıncılık. Goodman, N. (1968). Languages of art: An approach to a theory of symbols. Indianapolis: The Boss-Merrill Company, Inc.

Gould, G. (2017). Sonata no. 3 in e major, BWV 1016: III. Adagio ma non tanto (remastered) [Video]. Erişim adresi: https://www.youtube.com/watch?v=JOjIqpQNoJc

Goulish, M. (2005). A transparent lecture. G. Butt (Ed.), After criticism: New responses to art and performances (s. 176-206) içinde. Malden, USA: Blackwell Publishing.

Göktepe, S. (1984). Müzik sözlüğü, edebiyatı, felsefesi. İzmir: Yeniyol Matbaası.

Hamilton, A. (2008). Aesthetics and music. London \& New York: Continuum International Publishing Group.

Hampshire, S. (1966). Types of interpretation. S. Hook (Ed.), Art and philosophy / A symposium (s. 101-108) içinde. New York: New York University Press.

Hekman, S. (2012). Bilgi sosyolojisi ve hermeneutik: Mannheim, Gadamer, Foucault ve Derrida (H. Arslan ve B. Balkız, Çev.). İstanbul: Paradigma Yayınları.

Jose. (2012, 4 Mart). Rimsky-Korsakov: Scheherazade / Gergiev · Vienna Philharmonic · Salzburg Festival 2005 [Video]. Erişim adresi: https://youtu.be/SQNymNaTr-Y?t=2185

Kabir. (2011, 4 Ekim). Mozart - Voi che sapete (Cecilia Bartoli) HD subtitles [Video]. Erişim adresi: https://youtu. $\mathrm{be} / \mathrm{mDeFdGzthV0?t=123}$

Karadeniz, İ. (2017). Dış merkezli bir sıra dışılık: Eksantrisite. Ç. Adar (Ed.), VIII. Uluslararası Hisarlı Ahmet Sempozyumu Tam Metin Kitabı / Müzik Medya Teknoloji (s. 272-279) içinde. Kütahya: Dumlupınar Üniversitesi.

Karadeniz, İ. (2018). Kerem'in görünmez perdeleri. Ç. Adar (Haz.), IX. Uluslararası Hisarlı Ahmet Sempozyumu: 10-12 Mayıs 2018 / Tam Metin Kitabı / Müzik Teorileri (s. 205-222) içinde. Afyonkarahisar: Matbaa-i Beka.

Karadeniz, İ. (2020a). Program müziği kavramına hermeneutik bir yaklaşım. YEDİ, 23, 21-33. doi:10.17484/ yedi. 579048

Karadeniz, İ. (2020b). Saygun müziğinde makam soyutlamalart: Piyano konçertosu, op. 34, I (Doktora tezi, Hacettepe Üniversitesi, Ankara). Erişim adresi: https://tez.yok.gov.tr/UlusalTezMerkezi/

Karadeniz, M. E. (t.y.). Türk mûsikîsinin nazariye ve esasları. İstanbul: Türkiye İş Bankası Kültür Yayınları.

Kivy, P. (2007). Music, language, and cognition / And other essays in the aesthetics of music. New York: Oxford University Press.

Kütahyalı, Ö. (1996, Nisan). Yorum ve yorumcunun konumu. Orkestra, 35(268), 9-16.

Lewis, C. T. (1891). An elementary Latin dictionary. New York: Harper \& Brothers.

Lukács, G. (1999). Estetik I (3. bs.) (A. Cemal, Çev.). İstanbul: Payel Yayınevi.

Mach, E. (1991). Great contemporary pianists speak for themselves: Two volumes bound as one: Volume I. New York: Dower Publications, Inc.

Margolis, J. (1965). The language of art \& art criticism: Analytic questions in aesthetics. Detroit: Wayne State University Press.

Margolis, J. (1992). Robust relativism. G. Iseminger (Ed.), Intention \& interpretation (s. 41-50) içinde. Philadelphia: Temple University Press. 
Marx, K. (1968). Ökonomisch-philosophische manuskripte aus dem Jahre 1844. Karl Marx \& Friedrich Engels: Werke - ergänzungsband (s. 465-588) içinde. Berlin: Dietz Verlag Berlin GmbH.

Monsaingeon, B. (1989). Of Mozart and related matters: Glenn Gould in conversation with Bruno Monsaingeon. T. Page (Ed.), The Glenn Gould reader (s. 32-43) içinde. New York: Alfred A. Knopf.

Moran, B. (1988). Edebiyat kuramları ve eleştiri (6. bs.). İstanbul: Cem Yayınevi.

Mozart, W. A. (t.y.). Le nozze di Figaro, Akt I und II; KV 492, 1785 [Nota]. Erişim adresi: https://digital.staatsbibliothek-berlin.de/werkansicht?PPN=PPN655637907\&PHYSID=PHYS_0181\&DMDID=DMDLOG_0023

Mozart, W. A. (1999). Le nozze di Figaro / Die hochzeit des Figaro KV 492 / vocal score. Basel-London-New York-Praha: Bärenreiter-Verlag Karl Vötterle GmbH \& Co.

Özkan, H. D. (2007). Avrupa sanat müziği bağlamında eleştiri (Yüksek lisans tezi, İstanbul Teknik Üniversitesi, İstanbul). Erişim adresi: https://tez.yok.gov.tr/UlusalTezMerkezi/

Palisca, C. V. (1980). Theory, theorists. S. Sadie (Ed.), The new Grove dictionary of music and musicians, vol. 18 (s. 741-762) içinde. London: Macmillan Publishers.

Rimski-Korsakov, N. (1956). Scheherazade, op. 35: Festival at Baghdat. I. Iordan (Ed.), Complete collected works, vol. 22 (s. 76-122) içinde. Moskova: Muzgiz. Erişim adresi: https://s9.imslp.org/files/imglnks/usimg/2/2e/IMSLP01509-Rimsky_Scheherazade_4.pdf

Saygun, A. A. (1946). Yunus Emre (soli, koro ve orkestra için) oratoryo, 3 bölüm, op. 26. Ankara: Millı̂ Eğitim Basimevi.

Saygun, A. A. (1969). Yunus Emre: Oratorio for solo voices, mixed chorus and orchestra - score. New York - Hamburg: Southern Music Publishing Co. Inc.

Saygun, A. A. (2007). Yalancı dünyaya konup göçenler. [Ö. Yılmaz tarafindan]. Tenor Ömer Yllmaz: Opera ve konser kayıtları - aryalar [CD] içinde. İstanbul: Dexia. (2005)

Scruton, R. (2009). Understanding music: Philosophy and interpretation. London \& New York: Continuum International Publishing Group.

SinfonicadeGalicia. (2015, 26 Mayıs). Rimsky-Korsakov: Scheherazade op.35 - Leif Segerstam - Sinfónica de Galicia [Video]. Erişim adresi: https://youtu.be/zY4w4_W30aQ?t=2668

SuperClassic Channel. (2019, 12 Şubat). Bach violin sonata no.3 BWV 1016 (Leonid Kogan 1972) [Video]. Erişim adresi: https://youtu.be/U3fRnSGLd5o?t=537

Swafford, J. (1998). Johannes Brahms: A biography. London: Macmillan.

Thom, P. (2006). Toward a broad understanding of musical interpretation. Revue internationale de philosophie, 238(4), 437-452. Erişim adresi: https://www.cairn.info/revue-internationale-de-philosophie-2006-4-page-437.htm

Trottmann, C. (2017, 8 Şubat). Catherine Trottmann - Voi che sapete [Video]. Erişim adresi: https://youtu.be/ Rd3-K8ThAek?t=112

Walker, A. (1998). Musical criticism. Encyclopadia britannica içinde. Erişim adresi: https://www.britannica.com/ topic/musical-criticism 
